Bal, M.-C., Rendu C., Ruas M.-P., Campmajo P., 2010, Paleosol charcoal : Reconstructing vegetation history in relation to agro-pastoral activities since the Neolithic. A case study in the Eastern French Pyrenees. Journal of Archaeological Science, 37(2010) 1785-1797.

Accepted manuscript published in Journal of Archaeological Science 37 (2010) 1785-1797

http://dx.doi.org/10.1016/j.jas.2010.01.035

\title{
Paleosol charcoal: Reconstructing vegetation history in relation to agro-pastoral activities since the Neolithic. A case study in the Eastern French Pyrenees
}

\author{
Marie-Claude Bal \\ GRAMP (Grup de Recerca en Arees de Muntanya i Paisatge), Despatx B9/1 100, Departament de \\ Geografia, edifici B, Universitat Autonoma de Barcelona, 08193 Bellaterra, Espagne \\ Christine Rendu \\ FRAMESPA UMR5136, 5 allées Antonio Machado, 31058 Toulouse Cedex 9, France \\ Marie-Pierre Ruas \\ UMR 7209 CNRS-MNHN, 55 rue Buffon, 75231 Paris cedex 05, France \\ Pierre Campmajo \\ Chercheur associé, TRACES-CRPPM-UMR 5608, 39 Allées Jules Guesde, 31000 Toulouse, France
}

\begin{abstract}
This article uses a method that combines pedoanthracological and pedo-archaeological approaches to terraces, complemented with archaeological pastoral data, in order to reconstruct the history of ancient agricultural terraces on a slope of the Enveitg Mountain in the French Pyrenees. Four excavations revealed two stages of terrace construction that have been linked with vegetation dynamics, which had been established by analyses of charcoal from the paleosols and soils of the terraces. Pedo-archaeological descriptions of these terrace soils reveal their ancient origins and their long-term use. Their chronology was established by radiocarbon dating of single charcoal fragments and charcoal lenses originating in the paleosols. Combining radiocarbon dating with pedo-archaeology resulted in a more reliable chronology. Moreover, the Bronze Age was found to be a crucial period in the history of land-use. This study also highlights the role of fire in the construction of this land-use pattern.
\end{abstract}

\section{Introduction}

Soil terracing, present in most of the mountainous regions of the world, is one of the most spectacular human modifications of the landscape. The study of ancient agricultural terraces, in association with their soils, represents an essential historical source and enables a better understanding of the anthropic change of landscape (Sandor, 2006). This study combines pedoanthracological analyses and pedo-archaeological descriptions of terrace excavations situated between 1600 and 2000 $\mathrm{m}$ altitude in the Eastern Pyrenees. The aim is to reconstruct the history of terrace systems in relation to the landscape and to land-use changes since the Neolithic period. 
Bal, M.-C., Rendu C., Ruas M.-P., Campmajo P., 2010, Paleosol charcoal : Reconstructing vegetation history in relation to agro-pastoral activities since the Neolithic. A case study in the Eastern French Pyrenees. Journal of Archaeological Science, 37(2010) 1785-1797.

As important as it may seem, soil terracing has been little studied in Europe in a multi-proxy approach that combines geoarcheological excavations with pedosedimentary and chemical analyses of elements from the terrace soil (palaeoenvironment and archaeology). In Greece and southern France, Poupet (2000) and Harfouche (2007) combined pedology and archaeology to shed light on ancient agricultural terrace systems. In Italy, in Vislario, Nisbet (1983) has studied agricultural terrace soils using pedoarchaeological descriptions, the micromorphology of paleosols, and analyses of phytolith and charcoal. His study showed the benefits of this method for understanding the relationship between terrace construction and landscape changes over time in a mountain system since the Second Iron Age.

Interdisciplinary approaches are more common in Latin America. In these studies, pedology allowed them to detect paleosols or BT horizons that indicated the ancient origins of agricultural terrace systems.

In the Peruvian Andes, Sandor and Eash (1991, 1995; Sandor, 2006) have shown the interest of complementing the pedological descriptions of terrace soils and paleosols with radiocarbon dates of charcoal from these paleosols. This information, placed within the surrounding archaeological context, enabled them to reconstruct the agricultural history of the Colca Valley. When successive paleosols can be observed (Chicha-Soras Valley), radiocarbon dating of charcoal extracted from paleosols provides information about phases of use, abandonment and reconstruction of the terraces (Kemp et al., 2006) at different cultural periods.

It is also possible to identify cultivated plant species through different methods: 1) palynological analyses carried out on a sedimentary sequence situated close to the terraces (Branch et al., 2007); 2) stable carbon isotopes present in organic matter (Webb et al., 2004); 3) pollen, phytolith and diatom analyses in the terrace soil (Trombold and Israde-Alcantara, 2005). This latter study in Quemada, Mexico, also localized the cultivation of different agricultural products (Agave, Oppuntia and Zea mays) in the upper and lower parts of the entire terrace system. The question of the chronology of agricultural systems is a key part of these articles, which highlight the difficulty in obtaining precise dating of the construction and use of terraces. These uncertainties are essentially linked to the reworking of soils and paleosols before their protection and, therefore, the reworking of elements that they contain, i.e. charcoal and pottery. One article in particular (Borejsza et al., 2008) focuses on the establishment of a chronology of agricultural terrace systems and colluvium deposits of La Laguna in Mexico. The chronology of these terraces was obtained by describing their pedosedimentary history and by using radiocarbon dating and the OSL method (Optically Stimulated Luminescence).

Our study in the Pyrenees (Fig. 1) treats: 1) excavations which systematically revealed two generations of terraces as evidenced by paleosols connected with buried terrace walls, 2) the movement of charcoal in these soils and the use of charcoal radiocarbon dating to reconstruct chronology, and 3) the relationship between vegetation dynamics, the role of fire, and ancient agropastoral activities. The results emphasize the importance of the Bronze Age period in the anthropic shaping of the mountain landscape. Finally, we propose a taphonomical model to shed light on the relationship between charcoal and paleosol.

\section{Study area}

The study area is located in the Eastern Pyrenees, in the Cerdagne region (Fig. 1), which is a vast plateau surrounded by mountains at $100 \mathrm{~km}$ west of the city of Perpignan. Annual mean 
Bal, M.-C., Rendu C., Ruas M.-P., Campmajo P., 2010, Paleosol charcoal : Reconstructing vegetation history in relation to agro-pastoral activities since the Neolithic. A case study in the Eastern French Pyrenees. Journal of Archaeological Science, 37(2010) 1785-1797.

precipitation is $637 \mathrm{~mm}$. The Carlit Mountain range is a granite relief that dominates the plateau and reaches $2921 \mathrm{~m}$ in altitude. The Enveitg slope forms the western part of this mountain range, and is oriented towards the south. The Enveitg slope is 2000 ha in size and ranges from 1200 to $2600 \mathrm{~m}$ in altitude (Fig. 2).

After the high altitude plateau of Maura and La Padrilla $(2300 \mathrm{~m})$, which was leveled out by fluvioglacial erosion, the mountain slopes down gently forming a nearly flat zone at an altitude of $2100 \mathrm{~m}$ called the Pla de l'Orri. There is a peat bog in the center which has been the subject of palynological analysis (Galop, 1998). The soils found there are not highly differentiated, such as rankosols and thicker soils such as brunisols. The environment is covered with grass, with occasional Juniperus communis, Juniperus nana, Pinus uncinata and Cytisus purgans. Between 2100 and 1900 m, the slope becomes steeper and reveals large blocks and boulders of granite lodged in the granite sand. On these soils, which are thinner and poorer in organic matter (lithosols), the vegetation that has developed is composed of P. uncinata, J. communis and J. nana, C. purgans, and Calluna vulgaris. At $1900 \mathrm{~m}$, l'Orri d'en Corbill is a small pass with a gentle slope where rankosols developed, enriched by sediment from the slope. At the bottom of the slope, near the Brangoly stream, between 1500 and 1700 $\mathrm{m}$, is a zone of large meadows enclosed by drystone walls called Devesas del Cavaller. These meadows have been re-colonized by C. purgans, J. communis and J. nana, Ilex aquifolium, Rosa canina, Salix ef pirenaica, P. uncinata and Pinus sylvestris, and Rhododendron ferrugineum. The terraces excavated in this study are located at l'Orri d'en Corbill and Devesas de Cavaller.

\section{Archaeological context and vegetation history}

The terraces analyzed here are located within a pastoral zone in which archaeological research has been ongoing for 20 years. At first, these excavations focused exclusively on pastoral sites at high altitude. Surveys have revealed 58 sites. 18 of them (spread among 1900, 2100, 2200 and $2350 \mathrm{~m}$ in altitude) have been excavated (Fig. 2). They documented 49 levels of occupation which range from $5700 \mathrm{cal} \mathrm{BC}$ (7650 cal. yr BP) to the present day (Rendu, 2001, 2003). Three peat bog cores were extracted at altitudes of 2100, 2200 and $2350 \mathrm{~m}$ for sedimentary charcoal and palynological studies (Galop, 1998; Vannière et al., 2001). Results were compared to the archaeo-anthracological and carpological studies of pastoral site layers (Davasse et al., 1997; Ruas, 2003).

The Neolithic and Chalcolithic sites, dating from 4200 to 3200 cal BC (6150-5150 cal. yr BP), are located at $2100 \mathrm{~m}$ and ca. $2300 \mathrm{~m}$ at the limit of the ancient timberline, and seem to correspond to a bipolar system using mid-altitude forest clearances and alpine pastures. Increases in pollinic pastoral indicators (Plantago lanceolata, Rumex and Artemisia, Cichorioideae, Chenopodiaceae) and fire frequency show that forests were cleared for pastoral landuse (Galop, 1998; Vannière et al., 2001) from ca. $3000 \mathrm{cal} \mathrm{BC}$. This first expansion of grazing land has since been confirmed in other sites in the Pyrenees (Galop, 2006; Miras et al., 2007). The Bronze Age (around 2200-800 cal BC; 41502750 cal. yr BP) at Enveitg is marked by an increase in the fire frequency (Vannière, 2001) and in pollinic pastoral indicators (Galop, 1998). Deforestation concerned primarily the medium altitude forest, and some of the pinewoods at higher altitudes. This anthropogenic impact was accompanied by the construction of large structures. For example, at 2100 m, site 88 (1800-1200 cal BC; 3750-3150 cal. yr BP) appears more likely to have been a summer farm than a simple shepherd's hut. Data obtained from the western Pyrenees (Calastrenc et al., 2006; Rendu et al. in press) and in the Alps 
Bal, M.-C., Rendu C., Ruas M.-P., Campmajo P., 2010, Paleosol charcoal : Reconstructing vegetation history in relation to agro-pastoral activities since the Neolithic. A case study in the Eastern French Pyrenees. Journal of Archaeological Science, 37(2010) 1785-1797.

(Walsh et al., 2005) also confirm that the Bronze Age was a significant period of anthropic construction of mountainous slopes. Previous research has only considered this high level of Bronze Age organization from a pastoral point of view. However, the data presented in this article allows for a more complex understanding of the interactions between agrarian and pastoral practices.

The period $500 \mathrm{cal}$ BC-400 cal AD (2450-2350 cal. yr BP; Iron Age and Antiquity) is marked by a continuous decline in pastoral indicators, well under way from $900 \mathrm{cal}$ AD (2850 cal. yr BP) onwards, and by a long phase of pine re-colonization (Galop, 1998). Pastoral sites were rare and agropastoral activities appear to have relocated to the foothills. Two charcoal kilns found at $2100 \mathrm{~m}$ altitude, between $100 \mathrm{cal} \mathrm{BC}$ and $200 \mathrm{cal} \mathrm{AD;} \mathrm{2050-1750} \mathrm{cal.} \mathrm{yr} \mathrm{BP),} \mathrm{reveal} \mathrm{pinewood} \mathrm{exploitation,}$ probably for metallurgy. Pollinic pastoral indicators and cereal percentages increase again from 500 cal AD (1450 cal. yr BP). At an altitude of $1900 \mathrm{~m}$, carpological analysis revealed the presence of rye seeds in a hut from the Early Middle Ages (Ruas, 2003). This evidence and the presence of ancient terraces suggest that local agriculture existed during this period.

During the High Middle Ages (1200-1450 cal AD (750-500 cal. yr BP)), massive forest clearings changed the landscape, which then came to resemble its current state. Forest taxa reached its lowest percentage, while archaeological and palynological data show that the mountain economy was increasingly specialized in pastoral activities.

\section{Methods}

\subsection{A pedoanthracological approach}

Pedoanthracology was defined by Thinon (1992) and developed by Carcaillet and Thinon (1996) with the aim of studying vegetation dynamics from the Holocene (Thinon, 1992; Talon, 1997; Carcaillet, 2001a,b) using charcoal originating from mountain soils undisturbed by man (and thus the exclusion of archaeological contexts) (Thinon, 1992). Usually, pedoanthracological samples are taken every 5-10 $\mathrm{cm}$, from the bedrock towards the surface of the pit, after having made pedological descriptions of the varied soil horizons. Any colluvium or bioturbation traces are also noted.

The case of terraces is different, as their soils are greatly disturbed. More often than not, terrace construction begins with the building of a wall on the substrate, followed by back-filling of the gap between the wall and slope. On the one hand, the disturbance of soils connected with the construction of the terrace also results in the disturbance of the charcoal in these soils (Sanborn et al., 2006; Kemp et al., 2006). Yet, on the other hand, the construction of a wall leads to the accumulation of charcoal connected with the various phases of exploitation, abandonment, or re-use of the terrace. This mixture of charcoal from multiple phases means that a particular methodological approach is required. Archeopedological descriptions of soils and paleosols from the terraces reveal their construction methods as well as longterm changes. These descriptions allow a charcoal sampling methodology to be developed and an analysis of the radiocarbon dates from charcoal to be done on a case-by-case basis. Examining the origins of the charcoal and its preservation in this geoarchaeological context is indispensable for constructing a hypothetical model of the agricultural use of these terraces in relation to the changing vegetation dynamics since the Neolithic period. The charcoal mass $(1 / 4$ specific anthracomass, AM) is expressed as $\mathrm{mg}$ of extracted charcoal per $\mathrm{kg}$ of dry soil fraction finer than $5 \mathrm{~mm}$, excluding stones. 
Bal, M.-C., Rendu C., Ruas M.-P., Campmajo P., 2010, Paleosol charcoal : Reconstructing vegetation history in relation to agro-pastoral activities since the Neolithic. A case study in the Eastern French Pyrenees. Journal of Archaeological Science, 37(2010) 1785-1797.

\subsection{Sampling}

The four pits discussed in this article were chosen from among eleven pits that were excavated along an altitudinal transect (Figs. 2 and 3).

Seven of these correspond to terrace pits, all of which present a paleosol and a buried terrace. Among the seven, three (Cerd5- Cerd5bis, Cerd6 and Cerd13) are situated between 1600 and $1700 \mathrm{~m}$ altitude at Deveses del Cavaller, on the west-facing slope; three (Cerd3bis, Cerd11 and Cerd9) were excavated at $1900 \mathrm{~m}$ altitude at Orri d'en Corbill, on the south-facing slope; two of them were dug at $2100 \mathrm{~m}$ altitude at Pla de l'Orri (also on the south-facing slope), one of which was in an archaeological context (Cerd7) the other on pasture ground (Cerd8).

Another pit was excavated on pasture soil (Cerd2) at $2350 \mathrm{~m}$ altitude. Lastly, the pit Cerd12 at Orri d'en Corbill is located uphill from an ancient enclosure wall; two charcoal kilns were found in this pit buried underneath more than $1.50 \mathrm{~m}$ of sediment. The four pits discussed in this article are the most representative of the excavations conducted on terrace soil, namely: Cerd6, Cerd5- Cerd5bis, Cerd 13 and Cerd3bis.

The pits (ca. 2 _ $4 \mathrm{~m}$ ) were excavated by mechanical shovel from the front towards the back of the terrace. In two cases (Cerd3bis and Cerd13), the pit openings were widened (to $20 \mathrm{~m} 2$ ) to verify whether stones found in the profiles corresponded to walls. Clear alignments of stones were found which are consistent with a buried terrace.

Sample levels were defined according to pedo-archaeological descriptions of altitude terraces (Harfouche et al., in press; Harfouche and Poupet, 2004). All the pits excavated on the terraces show the same profile characterized by a paleosol connected to a buried terrace which lies under the current terrace. The organo-mineral horizon of this paleosol contains a large quantity (mass) of charcoal. Two or three sample levels were defined in the paleosol: one level, situated deep in the horizon of decomposition and alteration of the granite bedrock (horizon C); and one or two levels in the organomineral horizon of the paleosol. The terrace soil, which had undergone a new pedogenesis since covering the paleosol, has also been divided into two to three sample levels. The samples were taken from the base towards the surface of the pit in order to avoid contamination between levels. Each section was described using the pedological referential of AFES (1995).

\subsection{Charcoal extraction and radiocarbon dating}

Charcoal extraction was performed by flotation. This operation is carried out using a column of sieves of different mesh sizes $(5 ; 2 ; 0.8$ and $0.4 \mathrm{~mm})$. A binocular microscope is used for sorting, in order to extract the charcoal to be identified. Charcoal was observed under an incident light microscope (100x, 200x, 500x) and was identified in reference to the literature (Jacquiot et al., 1973; Schweingruber, 1990) and to a charred wood reference collection. Charcoal fragments impossible to identify were ascribed to "n.id." or "vitrified." "Vitrified" charcoals are those that have reflective properties like a mirror and have no visible anatomical structure (Touflan and Talon, 2009). For the moment, the way they are produced is unknown.

Twelve samples from terrace excavations were dated by AMS 14C (Table 1). Each date corresponds to one fragment of charcoal. AMS 14C dating was carried out at the VERA laboratory (Austria) and the POZNAN laboratory (Poland). The dates were calibrated as BP and as AD/BC by 
Bal, M.-C., Rendu C., Ruas M.-P., Campmajo P., 2010, Paleosol charcoal : Reconstructing vegetation history in relation to agro-pastoral activities since the Neolithic. A case study in the Eastern French Pyrenees. Journal of Archaeological Science, 37(2010) 1785-1797.

the CALIB program (Stuiver and Reimer, 1993) version 5.0 based on the data set Intcal04 (Reimer et al., 2004), and reported as intercept with 2 sigma.

\section{Results}

\subsection{Excavation descriptions}

At Deveses del Cavaller, the Cerd6 and Cerd5bis pits are at a distance of approximately $10 \mathrm{~m}$ from each other. The Cerd13 pit is situated in the same agricultural terracing system. The Cerd6 pit (Fig. 4, Table 2), $2 \mathrm{~m}$ deep, shows two superimposed terraces, the first one of which is buried and is connected with a $1 \mathrm{~m}$ thick paleosol (Harfouche et al., in press; Bal, 2006, 2008; Bal et al., 2008). The soil of the second terrace that covers the paleosol is developed, indicating that it could be ancient. In the upper part of the paleosol, a charcoal lens (99.9\% of charcoal for a lens) was found that has been preserved by a rapid arrival of sediment, which in turn has undergone pedogenesis. This second organo-mineral horizon, overlying the lens, also corresponds to the buried terrace. Six sample levels were delimited within the pit. Level I corresponds to the organo-mineral horizons, with Ah1 and Ah2 containing a significant root system. Level II corresponds to the eluvial horizon E and is marked by biological activity featuring the presence of Lumbricidae galleries and turricules. Level III is delimited by a redbrown BP horizon with more angular aggregates. Levels IV and V were taken from the organo-mineral horizon $2 \mathrm{bAh}$ of the paleosol which contained large quantities of charcoal. This last level was further divided into two sample levels. Level VI corresponds to the pedological horizon Sal. A few fragments of the charcoal lens identified as Abies alba found at the surface of the paleosol were sampled.

A first test pit, Cerd5, situated at $10 \mathrm{~m}$ from Cerd6, also contained a charcoal lens of A. alba dated 4713-4528 cal BP at a depth of 70-80 cm.

This observation led us to open a second pit in the same terrace, Cerd5bis (Fig. 5, Table 3). It contains two stages of terraces much like those found in Cerd6. The soil retained by the wall of the upper terrace covered a paleosol corresponding to a buried terrace. The whole of the pit was subject to five sample levels. The first (from 5 to $20 \mathrm{~cm}$ ) corresponds to both the surface organo-mineral horizon, Ah1, and also to the underlying organo-mineral horizon, Ah2, in which a highly developed root system as well as significant biological activity were found. The second sample level corresponds to the pedological horizon BP. Level III was sampled in the organomineral horizon $2 \mathrm{bAh}$ of the paleosol, this level being richer (244 ppm) in charcoal than other levels in the same pit (Level II: $11 \mathrm{ppm})$.

Level IV corresponds to the structural aluminic horizon (Sal), while level V corresponds to the alteration of the bedrock horizons annotated $\mathrm{C}$.

Pit Cerd13 (Fig. 6, Table 4) contains a buried terrace with stone blocks of significant size underneath the upper terrace. The soil which cover the paleosol is differentiated. Four levels were delimited over the whole of the structure. The first corresponds to the pedological horizons Ah2 and E. The BP horizon, situated just above the paleosol and part of the recent terrace soil, was chosen as the second level. Level III corresponds to the organo-mineral horizon of the paleosol. Level IV corresponds to an ancient E horizon (ochre-orange color) and is dated earlier than the buried terrace construction. 
Bal, M.-C., Rendu C., Ruas M.-P., Campmajo P., 2010, Paleosol charcoal : Reconstructing vegetation history in relation to agro-pastoral activities since the Neolithic. A case study in the Eastern French Pyrenees. Journal of Archaeological Science, 37(2010) 1785-1797.

This level was covered by the organo-mineral horizon ( $2 \mathrm{bAh})$ of the paleosol. The $2 \mathrm{bAh}$ horizon was initially retained by the wall of the buried terrace, but the wall later collapsed and the $2 \mathrm{bAh}$ horizon slid over the top of the wall.

The pit Cerd3bis (Fig. 7, Table 5) revealed the same layout of two successive terrace systems. However, the Ah2 horizon does not correspond to a sudden addition of sediment but rather to a slow process of accretion. This accretion process corresponds to sediment which slid down the slope and then differentiated, and covered the buried terrace after abandonment. The first sample level (level I) corresponds to the surface organo-mineral horizon (Ah1) and contains several roots and micro-roots. Level II, between 25 and $45 \mathrm{~cm}$ deep, corresponds to the Ah2 horizon. The organomineral horizon (2bAh) of the paleosol connected with the terrace represents level III of the sample. A final level IV was sampled in the horizon Sal and in the alteration of the bedrock horizons (C).

\subsection{Pedoanthracological results}

The ligneous paleovegetation was reconstructed from taxa identification and from current ecological characteristics of these taxa (Thinon, 1992).

All sample levels contain charcoal, from the bedrock to the surface horizon. Identification to genus level is possible for charcoal sized _ $0.4 \mathrm{~mm}$. The two taxa most frequently identified are two conifers: A. alba and P. silvestris/uncinata (present respectively in 19 and 30 levels out of 33 levels sampled for the nine pits). Between $1700 \mathrm{~m}$ and $2100 \mathrm{~m}$, Ericaceae (C. vulgaris) and Papilionaceae (genus C. purgans) appear respectively in 5 and 6 levels out of 33 analyzed levels. Three additional taxa appear only rarely: Corylus avellana and Salix (cf pyrenaica) are present in only 1 level out of 33, level III (2bAh) of the Cerd3bis, and Juniperus (communis and J. nana) appear only in level II (Ah2) in the Cerd3bis pit. Unidentifiable charcoal is present in the sample levels corresponding to paleosol organo-mineral horizons from the Cerd6 and Cerd3bis pits. This charcoal cannot be identified because of their state of preservation (altered structure). All taxa that have been identified are also present today on the study site except for fir (A. alba). The pits present high total anthracomasses (ASM) (369

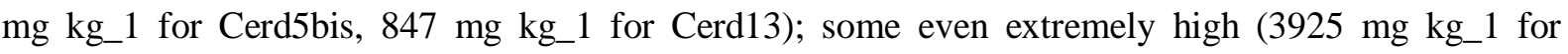
Cerd6; 1330 mg kg_1 for Cerd3bis). The pits are characterized by a high proportion of charcoal in the organomineral horizons of their paleosols. In fact, these horizons provide between $66 \%$ and $95 \%$ of the total anthracomass. Branch et al. (2007) also highlighted the importance of charcoal-rich horizons $\mathrm{Ah}$ and bAh corresponding respectively to the surface horizon and to the paleosol of an agricultural terrace profile situated in the Peruvian Andes. At $1700 \mathrm{~m}$ altitude in the shade, fir (A. alba) is present in Cerd6 and Cerd13 pits. Fir has not been identified in the surface level (I; Ah1 and Ah2 horizons) of the Cerd5bis pit. Pine (P. sylvestris/uncinata), which has been found in four levels of Cerd13, is absent from level V (base of 2bAh horizon) of the Cerd6 pit and from levels II (BP) and V (C) of the Cerd5bis pit. Vitrified charcoal fragments were found in level III (BP) and level V and VI of Cerd6. The best representation of fir can be found in the pedoanthracological profiles of Cerd6 and Cerd13, particularly in the 2bAh horizons, which correspond to level IV and V of Cerd6, (ASP: specific

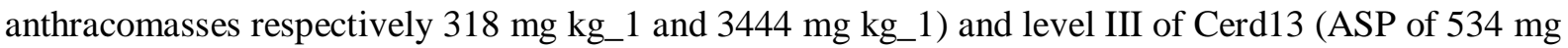
kg_1).

Charcoal extracted from the $2 \mathrm{bAh}$ horizon of paleosol (level III) of Cerd5bis reveals a mixed population of fir/pine with a dominance of fir $(210 \mathrm{mg} \mathrm{kg} 1$ for A. alba against $32 \mathrm{mg} \mathrm{kg} 1$ for P. uncinata/ sylvestris). This tendency rapidly diminishes and inverses in the surface levels (A. alba: 11 mg kg_1 in level II (BP) and P. uncinata/ sylvestris: 65mg kg_1 in level I, (Ah1 and Ah2 horizons)) (Figs. 4-6). 
Bal, M.-C., Rendu C., Ruas M.-P., Campmajo P., 2010, Paleosol charcoal : Reconstructing vegetation history in relation to agro-pastoral activities since the Neolithic. A case study in the Eastern French Pyrenees. Journal of Archaeological Science, 37(2010) 1785-1797.

At 1900 m altitude on the south-facing slope, pine and fir are present throughout the Cerd3bis pit (Fig. 7). Ericaceae and Papilionaceae (essentially small branches) have been identified in the $2 \mathrm{bAh}$ horizon of the paleosol and in the surface levels. Juniperus appears only in level II (Ah2), hazel (C. avellana) and willow (Salix (cf pirenaica)) were only identified in level III (2bAh). A significant proportion of unidentifiable species come from this same level. The vitrified charcoal fragments are poorly represented at the base ( $\mathrm{Sal})$ of the Cerd3bis profile. At this altitude, pine trees are found in greater abundance compared to firs throughout the whole of the pit and particularly in the organomineral horizon of the paleosol (2bAh) with an ASP of 786 mg kg_1 for the Cerd3bis pit. These pines are accompanied by shrub in this horizon and in certain levels above.

\subsection{Dating}

Samples of two taxa (Table 1), P. sylvestris/uncinata and A. alba, which dominate the assembling charcoal, were submitted for dating. The dating range from 4767-4612 cal. yr BP to 12831167 cal. yr BP (2817-2662 cal BC to 783-667 cal AD), i.e. from the Chalcolithic to the late Middle Ages.

Nine out of twelve dates are situated between the Chalcolithic and the Bronze Age (between 4767-4612 and 3362-3215 cal. yr. BP; 1412-1265 ca. BC). Out of these nine dates, six correspond to charcoal (fragments or lenses) from buried terrace paleosols. Only the Cerd3bis pit shows inversions in the age-depth relationship between the dates of the charcoal found in the organo-mineral horizon of the paleosol and the soil situated above. For the same pit Cerd3bis, an isolated charcoal fragment identified as P. uncinata/ sylvestris originating from the $2 \mathrm{bAh}$ horizon of the paleosol is dated during the transition Bronze Age/Iron Age (Vera-2951). Finally, the most recent dates, Antiquity (Poz-17560) and late Middle Ages (Poz-17564), correspond to charcoal found in the first $25 \mathrm{~cm}$ of the Cerd3bis and Cerd13 pits.

\section{Discussion}

\subsection{Dating and layers}

The charcoal lens (3933-3836 cal. yr BP; 1983-1886 cal BC; Vera-2949) of pit Cerd6 situated on the surface of the paleosol marks the end of the use of the paleosol. This end was nevertheless temporary, since a new pedogenesis indicates a second phase of usage of this same buried terrace. This change is dated during the Bronze Age. The lens of A. alba from the Cerd5 pit dating from 4713 to 4528 cal. yr BP (2763-2578 cal BC) is situated at the base of the $2 \mathrm{bAh}$ horizon of the paleosol. In this case, the dating provides an estimation that the bottom part of paleosol dates from the Chalcolithic. The 600-1100 years which separate these two lenses, as well as the re-use of the buried terrace of Cerd6, indicate a continuity in the paleosol's use and gives a coherent chronological framework for the dates obtained from the other paleosols in Deveses.

In fact, the dates obtained from isolated charcoal fragments in 1) the $2 \mathrm{bAh}$ from Cerd5bis (3977-3823 cal. yr BP; 2027-1873 cal BC), 2) the center of the wall of the agricultural terrace of Cerd13 (4767- 4612 cal. yr BP; 2817-2662 cal BC), 3) in level IV (ochre-orange horizon) which precedes the building of the wall (Cerd13: 4711-4512 cal. yr BP; 2761-2562 cal BC) and 4) at Cerd6 
Bal, M.-C., Rendu C., Ruas M.-P., Campmajo P., 2010, Paleosol charcoal : Reconstructing vegetation history in relation to agro-pastoral activities since the Neolithic. A case study in the Eastern French Pyrenees. Journal of Archaeological Science, 37(2010) 1785-1797.

within the BP horizon just above the paleosol (Cerd6: 3978-3829 cal. yr. BP; 2028-1879 cal BC), are all situated within the chronological bracket defined by the dates of the two lenses (4800-3800 cal. yr BP; 2850- 1850 cal BC). This range cannot be determined with complete certainty, however, because dates are established using charcoal from wood which may have already been dead for a long time before the fire (Gavin, 2003). Radiocarbon dating can overestimate the age of the event and this incertitude leads to classifying the use of buried terraces within a wide chrono-cultural period: the end of the Chalcolithic and the Bronze Age.

For the Cerd3bis pit, inversions of radiocarbon dating on charcoal from the $2 \mathrm{bAh}$ horizon contained in the buried terrace and from the Ah2 horizon have been observed (Table 1). The date 4743-4569 cal. yr BP (Vera 2950; 2793-2619 cal BC), obtained from a charcoal fragment from the $\mathrm{Ah} 2$ horizon, is dated 2000 years before those obtained from charcoal from the $2 \mathrm{bAh}$ horizon (Vera2951: 2889-2768 cal. yr BP; 939-818 cal BC). Within the 2bAh paleosol, the two dates are very far apart from each other: Vera- 2948 (2199-2117 cal BC; 4149-4067 cal. yr BP) and Vera-2951.

These date inversions are due to colluvium phenomena that resulted in a significant reworking of the charcoal in the soil and lead to even greater uncertainty regarding terrace dating (Sandor and Eash, 1995; Kemp et al., 2006). There are, however, limits to these re-workings: no charcoal is dated later than the end of the Bronze Age (Vera-2951) in the Ah2 and 2bAh horizons. Moreover, in all of the four pits, all the datings carried out on charcoal (fragments or lenses) from the paleosols connected with the buried terraces range from the Chalcolithic to the transition Bronze Age-Iron Age. The two most recent dates (Table 1) correspond to charcoal originating from the surface horizon (Cerd3bis: Poz- 17560: Antiquity and Cerd13-Poz-17564: late Middle Ages). Even though charcoal movements disturb the stratigraphy within each soil (Carcaillet and Thinon, 1996; Carcaillet, 2001a; Carnelli et al., 2004; Schwartz et al., 2005; Bal et al., 2008), it is possible to consider that the assembling charcoal follow a stratigraphy linked to the superposition of the paleosol and of the differentiated soil. In addition, the results from radiocarbon dating are remarkably consistent, since nine out of twelve datings give the same period of Chalcolithic - Bronze Age.

\subsection{Vegetation dynamics}

In all of the pits, pedoanthracological analyses reveal the presence of two dominant taxa, A. alba and P. sylvestris/uncinata, between 1600 and $1900 \mathrm{~m}$ altitude. In comparing plant dynamics, in all of the pits, fir- and pine-trees were observed in the deepest levels. Paleovegetation revealed by the assembling charcoal from the $2 \mathrm{bAh}$ horizons of thepaleosols showthat atanaltitudeof $1600 \mathrm{~m}$ (Cerd5bis, Cerd6 and Cerd13), the fir-tree predominated in a mixed population of fir and pine, whereas at $1900 \mathrm{~m}$ at Orri d'en Corbill, landscape vegetation was composed of pinewood accompanied by fir (Cerd3 bis). This vegetation profile is similar to the one observed for the end of the Iron Age until Antiquity in an archaeo-anthracological analysis of pastoral huts excavated at the same location (Davasse et al.,1997). At 2100mat Pla de l'Orri, in three pits not discussed in this article, the fir-treewas not identified (Bal, 2006). This altitude corresponds to the distribution of P. uncinata. Thus, all of the pedoanthracological profiles are consistent with the theoretical altitudinal distributions of taxa. Datings carried out on fragments of fir and pine show that they were present between 1600 and1900maltitudeduringtheendof the Chalcolithic Period and the Bronze Age (Table 1). Pine was present during the Iron Age, Antiquity and the late Middle Ages. 
Bal, M.-C., Rendu C., Ruas M.-P., Campmajo P., 2010, Paleosol charcoal : Reconstructing vegetation history in relation to agro-pastoral activities since the Neolithic. A case study in the Eastern French Pyrenees. Journal of Archaeological Science, 37(2010) 1785-1797.

The charcoal of superficial horizons, which date from after the abandonment of this first generation of terraces, shows that this vegetation transformation started from this period onwards. At $1700 \mathrm{~m}$ altitude, as at $1900 \mathrm{~m}$, the fir-tree was always present, but in smaller quantities, and the proportion of pine to fir was systematically inversed. Today, the fir is no longer part of the taxa present on the slopes studied here (but it can be found in the nearby valleys). Throughout the entire Enveitg slope, these results confirm the dynamics previously described based on the pollen record of Pla de l'Orri (Galop, 1998; Vannière et al., 2001). The presence of the fir-tree at Enveitg is documented from 7332 - 6686 cal. yr BP; 5383 - 4937 cal BC and it began to decline in ca. 54205321 cal. yr BP (3471-3372 cal BC, estimated age). The pedoanthracological and the archaeopedological data make it possible to link vegetation dynamics with the precise location of human activities on the slope.

\subsection{Reconstruction of an agro-pastoral landscape through charcoal analysis at the end of} Chalcolithic and during the Bronze Age

At the end of the Chalcolithic and during the Bronze Age, terraces were built between $1600 \mathrm{~m}$ and $1900 \mathrm{~m}$ altitude. Fire played a role in their construction and maintenance. The following elements suggest that there was not only one fire, but many: 1) the organo-mineral charcoal-rich horizons of the paleosol; 2) the nearby presence of two lenses, one situated at the base, the other at the summit of one of these horizons (Cerd5 and Cerd6); and 3) the dates obtained from charcoal. The succession observed at Cerd6 provides one possible model for human activity on the site: tree clearing, terrace construction, exploitation, end of exploitation, reforestation, fire (presence of the lens), small sediment contribution (covering of the lens), followed by a new phase of activity that always corresponded to the buried terrace. This model can be interpreted in different ways: slash-and-burn, with short phases of cultivation alternating with phases of reforestation, or perhaps long phases of exploitation interspersed with periods of abandonment. None of the evidence currently available enables us to privilege one hypothesis over another. Whatever the exploitation pattern that these terraces have undergone, the Bronze Age was a key period in the construction of soils on the Enveitg Mountain. Moreover, this importance of the Bronze Age period has also been shown by the results of archaeological excavations of pastoral sites on the slope (see above; Rendu et al., 2009). The high degree of organization of these pastoral sites is similar to those of the first generation of terraces.

At the regional scale, the hypothesis of the complexity of agropastoral systems in the Bronze Age is further supported by the data originating from the archaeological site of Llo. There, at $1600 \mathrm{~m}$, regular cultivation is suggested by the carpological analysis of carbonized seeds found in a Late Bronze Age dwelling. The farmers developed an agro-pastoral system which associated hulled barley (Hordeum vulgare) and peas (Pisum sativum) (Ruas et al., 2009). This system was also linked to the breeding of sheep, goats and cattle and with a diversified production (Bre hard and Campmajo, 2005). These data also suggest complex forms of agro-pastoral exploitation.

The second generation terrace soils have not been protected by post-deposit fossilization. It is impossible to date their use and to estimate the time interval which separates the two terrace generations. No element of absolute chronology allows us to date the cessation of exploitation on these superficial terraces. Potentially 1000-2000 years old, the soils of these terraces are the current soils. Archaeology, palynology, and historical sources distinguish many phases of abandonment (Antiquity and the Late Middle Ages) or expansion (Early and High Middle Ages and the modern period). These sources also distinguish different kinds of exploitation: possible slash-and-burn during the Early 
Bal, M.-C., Rendu C., Ruas M.-P., Campmajo P., 2010, Paleosol charcoal : Reconstructing vegetation history in relation to agro-pastoral activities since the Neolithic. A case study in the Eastern French Pyrenees. Journal of Archaeological Science, 37(2010) 1785-1797.

Middle Ages, grazeland clearing by fire during modern times, pastoral and meadow usages, and occasionally potato crops at the beginning of the 20th century. Pedoanthracology, however, reveals two long periods which corresponds to two successive soils, marked by different dynamics of fire, vegetation, and sedimentation.

\subsection{Taphonomical processes: charcoal production, dispersion and preservation}

\subsubsection{Charcoal production}

Charcoal, being the result of burnt vegetation, can be produced by different sources. The primary sources are natural forest fires caused by lightning or anthropogenic in relation to agropastoral practices (Carcaillet et al., 1997; Moore, 2000). Charcoal kilns or hut fireplaces, settlements situated on a slope, or any craft activity employing wood as fuel also produce charcoal, whose dispersion is possible after disassembling the structure. Charcoal can therefore be found diffused in the surrounding soils. Concerning the terraces, charcoal production can be linked to different practices. Fire is of course used for clearing a space for terrace construction (Alcaraz, 1999), as well as for the maintenance phase or re-exploitation after re-colonization by vegetation. Burning the vegetation can contribute to fertilization of the ground (Sigaut, 1975). A third situation also needs to be mentioned, not that of direct production but of charcoal contribution through manure which includes ashes and charcoal originating from the domestic hearth.

\subsubsection{Dispersion and bioturbation}

Charcoal then undergoes several processes such as dispersion and bioturbation (Carcaillet, 2001a,b; Sanborn et al., 2006) that contribute to their fragmentation and to their burial in the ground. In the first instance, wind and hydric erosion are responsible for the rapid dispersion and deposition of charcoal on the surface of the ground just after a fire (Clark, 1988; Trabaud, 1989; Thinon, 1992; Lynch et al., 2004). Charcoal fragments larger than $0.4 \mathrm{~mm}$ are generally not transported more than approximately $10 \mathrm{~m}$ during a fire (Ohlson and Tryterud, 2000), contrary to finer particles (around 100 microns) (Clark et al., 1998). However, the intensity of the fire, the production site's geographical location, and the weather conditions will determine whether one or the other will predominate.

Bioturbation leads to the presence of charcoal at different soil depths. This is generated by the action of Lumbricidae, of pararthropods, and of Formicidae which provoke the movement of charcoal by the creation of galleries in the soil (Davidson, 2002; Davidson et al., 2002). Numerous Coleoptera and larvae also live in the interstices of the soil. Scarabaeoidea larvae can be found in the Cerdagne soils at a depth of more than $40 \mathrm{~cm}$. Bioturbation caused by plant roots also significantly affects the soil. The root's progression in the soil while growing can lead to the fissuring of certain bedrocks. They create channels and lead to the mixing of diverse mineral and organic elements of the soil (Gabet et al., 2003). When a root dies, it frees up a channel which can be rapidly filled by the process of water infiltration. Roots participate therefore in the fragmentation of charcoal by creeping inside the anatomic structures (Thinon, 1992) as well as in their displacement in the soil. The alteration horizons of the bedrock usually contain charcoal, which proves the importance of burial. Vertical pedological processes caused essentially by soil mesofaune favor the incorporation of small pieces of charcoal into the surface horizons. 
Bal, M.-C., Rendu C., Ruas M.-P., Campmajo P., 2010, Paleosol charcoal : Reconstructing vegetation history in relation to agro-pastoral activities since the Neolithic. A case study in the Eastern French Pyrenees. Journal of Archaeological Science, 37(2010) 1785-1797.

All of these activities that contribute to the burial and the fragmentation of charcoal (Thinon, 1992; Talon, 1997) can also induce inversions in the relationship between the age of charcoal and the depth of the sample (Gavin, 2003). For soils at altitude above the timberline, the displacement of charcoal during transport by man (charcoal kiln production) is considered accidental (Talon, 1997). The absence of anthropogenic reworking of the soil also coincides with an absence of anthropogenic soil charcoal displacement (for example, by activities linked to agriculture). These movements are essentially due to solifluction, colluvium contribution, and bioturbation phenomena. Cattle trampling also disturbs the organo-mineral surface horizons in highly pastured zones.

The situation is completely different for terrace soils. They are also subject to bioturbation and colluvium contribution phenomena, but they are also highly reworked by human beings. This reworking is however not total: the supporting wall is built directly on the granite bedrock after having removed the soil, but on both sides of thiswall soil horizons can be preserved (Harfouche, 2007). Charcoal found in small quantities today in deep horizons, especially in bedrock alteration horizons, probably originate from fires prior to the construction of the buried terrace. The organo-mineral horizon of paleosols retained by buried terrace walls represents the agricultural soil horizon of these terraces. For each of these excavated terraces, the ancient surface horizon is rich in charcoal of a size greater than $0.8 \mathrm{~mm}, 2 \mathrm{~mm}$, and $5 \mathrm{~mm}$, with some being greater than $2 \mathrm{~cm}$ in diameter. These pedoanthracological results obtained on the terraces can be compared to those originating from soils undisturbed by humans and situated in the same geographical context. Two pedoanthracological pits excavated on pasture soil at $2300 \mathrm{~m}$ and $2100 \mathrm{~m}$ altitude, (Cerd2 and Cerd8 pits, not discussed here, Bal, 2006, p 97) contained very small charcoal fragments (sized $<0.8 \mathrm{~mm}$ ), with a respective total anthracomass of 22 and $450 \mathrm{ppm}$. Furthermore, their distribution in the soil is diffuse throughout the profile. Without neglecting bioturbation phenomenon, these differences in size, quantity and dispersion of charcoal suggest that the organo-mineral horizons of agricultural terrace paleosols contain a large proportion of charcoal as a result of terrace usage, which can therefore shed light on the type of soil management.

\subsubsection{Uses of terrace soil}

In order to identify the type of soil management, an analogue is needed which would allow for comparisons between soils linked to regular cultivation and soils resulting from slash-and-burn or burning grazeland for cultivation. The addition of manure often contains artifacts (shards of eroded ceramics) which have not been found in this study area. Yet this does not mean that manure was not added; it is possible that other fertilizing methods were used, such as direct fertilization by the herds.

One hypothesis for explaining the significant concentration of charcoal in the organo-mineral horizon of paleosols is that of fire clearings. These fires could play a role in complex technical and temporal cycles, as discussed above. The soils covering the paleosols are related to a second terrace generation. For all of the terraces, surface levels present much less charcoal than paleosol surface horizons (for example Cerd6-level IV: 327 ppm; Cerd6-level III: 19 ppm; Cerd6-level II: 1 ppm). The significant differences in anthracomass between paleosols and present soils represent two anthracocoenoses revealing at least two different types of paleovegetation, chronologically separated by a sufficiently long time lapse enabling the differentiation of the surface soil. The relative poorness in charcoal of the present soil horizons can be related to several phenomena, perhaps combined: 1) less tree cover, 2) less use of fire for agricultural purposes, 3) phases of pastoral use and 4) a lower rate of post-deposition preservation. 
Bal, M.-C., Rendu C., Ruas M.-P., Campmajo P., 2010, Paleosol charcoal : Reconstructing vegetation history in relation to agro-pastoral activities since the Neolithic. A case study in the Eastern French Pyrenees. Journal of Archaeological Science, 37(2010) 1785-1797.

\subsubsection{Preservation}

The covering over of paleosols results in remarkable charcoal preservation. For terrace construction, covering took place by colluvium contribution or by anthropogenic sediment addition. This event could have happened very quickly, leading to the preservation of charcoal and charcoal lenses. In this case, the protection would be maximal and therefore avoid transport and fragmentation of charcoal in the paleosol. When this process happens over a longer period of time, elements at the surface of the soil are able to undergo the diverse processes described in this article, i.e. dispersion and bioturbation, before the paleosols were covered. The quantity of paleosol charcoal alone, however, is not a sufficient indicator of the degree of protection, since quantity may be also linked to fire frequency or the duration of agricultural activities. It is therefore necessary to complement the quantity of charcoal with other elements: 1) a pedological description of the surface soil which indicates its age; 2) the degree of charcoal fragmentation; 3) the presence of charcoal lenses. At Cerd5 and Cerd6, the lenses indicate that a rapid covering prevented their fractioning and their dispersion. Furthermore, soils situated above the paleosols present differentiated horizons which therefore indicate their age of at least several centuries. Cerd13 and Cerd3bis also contain differentiated horizons. There is a difference, however, for the $\mathrm{Ah} 2$ and $2 \mathrm{bAh}$ horizons of Cerd3bis which results partly from colluvium additions containing charcoal of different ages. The preservation of charcoal within this paleosol is more difficult to interpret.

\section{Conclusions}

By combining pedoanthracological and pedo-archaeological approaches, this study has demonstrated that:

- Charcoals from paleosol and/or soil of agricultural terraces are good bio-indicators for reconstructing local vegetation dynamics related to agricultural practices and for showing the role of fire in ancient agriculture.

- The two stages of terraces are linked to successive phases of vegetation and correspond to different phases of construction and use (other authors show a similar model in the Peruvian Andes, Branch et al., 2007). For the moment, there is not enough evidence to date the beginning of the usage of the upper terrace.

- The Bronze Age seems to have been a turning point in the agropastoral construction, land-use, and transformation of the mountain landscape.

- The progressive disappearance of A. alba, which has been replaced by pine forest expansion in Enveitg slope since the Chalcolithic.

- In order to more accurately date and reconstruct the history of agricultural land-use, it is preferable to combine soil descriptions which estimate the antiquity of the terracing system with radiocarbon dates from charcoal in the paleosol.

- A charcoal taphonomical model in this complex context helps to disentangle the production and preservation of charcoal within the two stages of the terrace systems.

\section{Acknowledgements}

Financial support was provided by the Ministère de la Culture and the CNRS, program entitled "Cerdagne: estivage et structuration sociale d'un espace montagnard", and by a post-doctoral grant from the University Autonoma of Barcelona, Department of Geography, Gramp laboratory.We thank 
Bal, M.-C., Rendu C., Ruas M.-P., Campmajo P., 2010, Paleosol charcoal : Reconstructing vegetation history in relation to agro-pastoral activities since the Neolithic. A case study in the Eastern French Pyrenees. Journal of Archaeological Science, 37(2010) 1785-1797.

the Geode laboratory and Jean- Paul Me' tailie' for help and support during the doctorate; Elisabeth Bille, Marc Conesa, Denis Crabol, and Didier Galop for constructive discussions during field work and workshops; Brigitte Talon, Christopher Carcaillet, and Michel Thinon for pedoanthracological discussions; P. Poupet and R. Harfouche for the help during Enveitg sampling and soil descriptions. We would also like to thank Cynthia J. Johnson for her assistance in editing this article.

\section{References}

Alcaraz, F. 1999: Les terrasses méditerranéennes, entre terroirs et paysages (nord-ouest du bassin méditerranéen). Thèse de géographie, Toulouse, Université de Toulouse-Le Mirail, vol. I et vol. II.

Baise, D, Jabiol, B. and Gobat, J.M. 1995: Le référentiel pédologique. Association Française de l'Etude des Sols.

Bal, M.C. 2006: Constructions et dynamiques des espaces et des terrasses agro-pastoraux en zone intermédiaire des Pyrénées du Néolithique à nos jours (Cerdagne, Pays Basque et Pays de Sault), approche archéoenvironnementale par la pédoanthracologie. Thesis, Département de Géographie, laboratoire Geode, Université de Toulouse II. http://tel.archives-ouvertes.fr.

Bal, M.C, Harfouche R., Poupet P., Campmajo P. and Rendu C. 2008: Archaeoenvironmental studies of cultivation terraces in the Enveig mountain (Cerdagne) in Eastern Pyrenees (France), use of pedo-anthracology. In Bar International, editor, Proceedings of the III International Meeting of Anthracology, Lecce, juin 2004.

Bal, M.C. 2008: Approche géoarchéologique des terroirs montagnards par la pédoanthracologie: l'exemple de la montagne d'Enveig (Pyrénées Orientales, France). In Galop D. (dir), Paysages et environnement. De la reconstitution du passé aux modèles prospectifs. Besançon, Presses universitaires de Franche-Comté, 141-158.

Borejsza, A., Rodriguez-Lopez, I. Frederick, C.D. and Bateman, M.D. 2008: Agricultural slope management and soil erosion at La Laguna, Tlaxcala, Mexico. Journal of Archaeological Science, available online.

Branch N.P., Kemp R.A., Silva B.; Meddens F.M., Williams A., Kendall A. and Pomacanchari C.V. 2007: Testing the sustainability and sensitivity to climate change of terrace agricultural systems in the Peruvian Andes: a pilot study. Journal of Archaeological Science, 34, 1-9.

Bréhard S. and Campmajo P. 2005: Exploitation des animaux domestiques et structuration de l'espace montagnard à l'Âge du Bronze: Llo (Cerdagne, Pyrénées-Orientales), Anthropozoologica, $40,1,217-233$.

Calastrenc C., Le Couédic M., Rendu C., with collaboration of Bal M.-C. 2006 : Archéologie pastorale en vallée d'Ossau. Problématiques, méthodes et premiers résultats, Archéologie des Pyrénées Occidentales et des Landes, 25, 11-30.

Carcaillet, C. and Thinon, M. 1996: Pedoanthracological contribution to the study of the evolution of the upper treeline in the Maurienne Valley (North French Alps): methodology and preliminary data. Review of Palaeobotany and Palynology, 91, 399-416.

Carcaillet, C., Barakat, H.N., Panaistois, C. and Loisel, R. 1997: Fire and late-Holocene expansion of Quercus ilex and Pinus pinaster on Corsica. Journal of Vegetation Science 8, 85-94.

Carcaillet, C. 2001a: Are Holocene wood-charcoal fragments stratified in alpine and subalpine soils ? Evidence from the Alps based on AMS ${ }^{14} \mathrm{C}$ dates. The Holocene 11 (2), 231-242. 
Bal, M.-C., Rendu C., Ruas M.-P., Campmajo P., 2010, Paleosol charcoal : Reconstructing vegetation history in relation to agro-pastoral activities since the Neolithic. A case study in the Eastern French Pyrenees. Journal of Archaeological Science, 37(2010) 1785-1797.

Carcaillet, C. 2001b: Soil particles reworking evidences by AMS 14C dating of charcoal. Earth and Planetary sciences 332, 21-28.

Carnelli, A.L., Theurillat, J.P., Thinon, M., Vadi, G. and Talon, B. 2004: Past uppermost tree limit in the Central European Alps (Switzerland) based on soil land soil charcoal. The Holocene 14 (3), 393405.

Clark, J.S. 1988: Particle motion and the theory of charcoal analysis: source area, transport, deposition, and sampling. Quaternary Research 30, 67-80.

Clark, J.S., Lynch, J., Stocks, B.J. and Goldammer, J. 1998: Relationships between charcoal particles in air and sediments in west-central Siberia. The Holocene 8 (1), 19-29.

Davasse, B., Galop, D., and Rendu, C. 1997: Paysages du Néolithique à nos jours dans les Pyrénées de l'Est d'après l'écologie historique et l'archéologie pastorale. In J. Burnouf, J.P.

Davidson D.A. 2002: Bioturbation in old arable soils: quantitative evidence from soil micromorphology. Journal of archaeological science, 29: 1247-1253.

Davidson D.A., Bruneau P.M.C., Grieve I.C. and Young I.M. 2002: Impacts of fauna on an upland grassland soil as determined by micromorphological analysis. Applied Soil Ecology, 20: 133-143.

Gabet E.J., Reichman O.J. et Seabloom E.W. 2003: The effects of bioturbation on soil processes and sediment transport. The Annual Review of Earth and Planetary Science, 31: 249-273.

Galop, D. 1998: La forêt, l'homme et le troupeau dans les Pyrénées, 6000 ans d'histoire de l'environnement entre Garonne et Méditerranée. GEODE, Laboratoire d'Ecologie Terrestre, Framespa, Université Toulouse-Le Mirail.

Galop, D. 2006: La conquête de la montagne Pyrénéenne au Néolithique. Chronologie, rythmes et transformations des paysages à partir des données polliniques. In J. Guilaine (dir.) Populations néolithiques et environnement, Editions Errance : 279-295.

Gavin, D.G. 2003: Holocene fire history of a coastal temperate rain forest based on soil charcoal radiocarbon dates. Ecology 84, 186-201.

Harfouche, R. and Poupet, P. 2004: Construction et évolution des paysages montagnards : sols, paléosols et aménagements agricoles. Sondages dans les terrasses de la montagne d'Enveig. In Rendu C. and al, Estivage et structuration sociale d'un espace montagnard : la Cerdagne. Rapport PCR, 4759.

Harfouche, R. 2007: Histoire des paysages méditerranéens terrassés : aménagements et agriculture, BAR eds, International Series, 1634, Archaeopress, Oxford, 265p.

Harfouche, R., Poupet, P., Ruas, M.P., Campmajo, P., Rendu, C. and Bal, M.C. (in press): Aux marges de l'ager : forêt, pâturages et... agriculture dans la montagne pyrénéenne. In Actes VII ${ }^{\mathrm{e}}$ colloque AGER " Dynamique et gestion des forêts et des zones rurales marginales (friches, landes, marais...) ". Rennes, octobre 2004.

Jacquiot, C., Trenard, Y. and Dirol, D. 1973: Atlas d'anatomie des bois des Angiospermes (essences feuillues). Paris, Centre technique du bois.

Kemp, R, Branch, N., Silva, B., Meddens, F., Williams, A., Kendall, A. and Vivanco, C. 2006: Pedosedimentary, cultural and environmental significance of paleosols within pre-hispanic agricultural terraces in the southern Peruvian Andes. Quaternary International 158, 13-22.

Lynch J.A., Clark J.S. and Stocks B.J. 2004: Charcoal production, dispersal, and deposition from the fort providence experimental fire: interpreting fire regimes from charcoal records in boreal forests. Canadian journal of forest research, 34: 1642-1656. 
Bal, M.-C., Rendu C., Ruas M.-P., Campmajo P., 2010, Paleosol charcoal : Reconstructing vegetation history in relation to agro-pastoral activities since the Neolithic. A case study in the Eastern French Pyrenees. Journal of Archaeological Science, 37(2010) 1785-1797.

Miras, Y., Ejarque, A., Riera, S., Palet, J.M., Orengo, H.A., Euba, I. 2007: Dynamique holocène de la végétation et occupation des Pyrénées andorrannes depuis le Néolithique ancien, d'après l'analyse pollinique de la tourbière de Bosc dels Estanyons ( $2180 \mathrm{~m}$ ), Vall del Madriu, Andorre. Comptes Rendus Palevol. , 6, 4: 291-300.

Moore, J. 2000: Forest fire and human interaction in the early holocene woodlands of Britain. Palaeogeography, Palaeoclimatology, Palaeoecology, 164: 125-137.

Munsell 1994: Soil color charts (revised edition).

Nisbet, R. 1983: Vislario archeologia e paleoecologia di un terrazzamento alpino. Eds Corsac Geda.

Ohlson M. and Tryterud E. 2000: Interpretation of the charcoal record in forest soil: forest fires and their production and deposition of macroscopic charcoal. The Holocene, 10 (4): 519-525.

Poupet P. 2000. Science du sol et arche' ologie. A propos d'un exemple délien:archeology and the science of soil: on an example of Delos. Etudes Rurales

$153-154,1-114$

Reimer, P.J., Baillie, M.G.L., Bard, E., Bayliss, A., Beck, J.W., Bertrand, C., Blackwell, P.G., Buck, C.E., Burr, G., Cutler, K.B., Damon, P.E., Edwards, R.L., Fairbanks, R.G., Friedrich, M., Guilderson, T.P., Huguen, K.A., Kromer, B., McCormac, F.G., Manning, S., Bronk Ramsey, C., Reimer, R.W., Remmele, S., Southon, J.R., Stuiver, M., Talamo, S., Taylor, F.W., van der Plitch, J. and Weyhnemeyer, C.E. 2004: Intcal04 terrestrial radiocarbon age calibration, 0-26 cal kyr BP. Radiocarbon 46, 1029-58.

Rendu, C. 2001: Fouiller des cabanes de bergers : pour quoi faire ?, In J. Guilaine (dir.), La très longue durée, Etudes Rurales, 153-154, 151-176.

Rendu, C. 2003: La montagne d'Enveig, une estive pyrénéenne dans la longue durée. Canet, Trabucaire eds.

Rendu C., Calastrenc C., Le Couédic M., Galop D., Rius D., Cugny C. and Bal M.C. in press: Montagnes et campagnes d'Oloron dans la longue durée. Premiers résultats d'un programme interdisciplinaire. D'Iluro à Oloron Sainte-Marie, un millénaire d'histoire, Colloque de la Fédération Aquitania , 7-8-9 décembre 2005, à paraître dans les suppléments de la revue Aquitania.

Rendu, C., Bille, E., Conesa, M., Calastrenc, C., Campmajo, P., Crabol, D., 2009. Margins and centers in the shaping of the Pyrenean slopes. In: Medieval Dynamics within the Long-term Perspective, Medieval Rural Settlement in Marginal Landscapes, Ruralia VII, 8-14th September 2007, Cardiff. Brepols, Turnhout, pp. 235-251.

Ruas, M.P. 2003: Des céréales et des fruits dans le niveau incendié de la cabane 81, In Rendu C. $L a$ montagne d'Enveig. Une estive pyrénéenne dans la longue durée. Edition Trabucaire, Canet, 393-412.

Ruas, M.-P., Bouby, L., Campmajo, P., 2009. Agriculture en montagne cerdane au Bronze final: les données carpologiques de Llo-Lo Lladre (Pyrénées-Orientales), De Méditerranée et d'ailleurs., Mélanges offerts à Jean Guilaine. Archives d'Ecologie Préhistorique, Toulouse, pp. 639- 660.

Sanborn, P., Geertsema, M., Timothy Jull, A.J. and Hawkes B. 2006: Soil and sedimentary charcoal evidence for Holocene forest fires in an inland temperate rainforest, east-central British Columbia, Canada. The Holocene, 16, (3), 415-427.

Sandor, J.A. and Eash N.S. 1991: Significance of ancient agricultural soils for long-term agronomic studies and sustainable agriculture research. Agronomic Journal 83, 29-37.

Sandor, J.A. and Eash N.S. 1995: ancient agricultural soils in the Andes of southern Peru. Soil Science Society American Journal 59, 170-179.

Sandor, J.A. 2006: Ancient agricultural terraces and soils. In Warkentin ed., Footprints in the soil: people and ideas in soil history. Elsevier, Amsterdam. 
Bal, M.-C., Rendu C., Ruas M.-P., Campmajo P., 2010, Paleosol charcoal : Reconstructing vegetation history in relation to agro-pastoral activities since the Neolithic. A case study in the Eastern French Pyrenees. Journal of Archaeological Science, 37(2010) 1785-1797.

Schwartz, C., Thinon, M., Goepp, S., Schmitt, C., Casner, J., Rosique, T., Wuscher, P., Alexandre, A., Dambrine, E., Martin, C. and Guillet, B. 2005: Premières datations directes de défrichements protohistoriques sur les chaumes secondaires des Vosges (Rossberg, Haut-Rhin). Approche pédoanthracologique. C. R. Geoscience 337, 1250-1256.

Schweingruber, F.H. 1990: Anatomie europaïscher Hölzer - Anatomy of european woods. Eidgenössische Forschungsanstalt für Wald, Schnee und Landschaft, Birmensdorf. Bern und Stuttgart, Haupt.

Sigaut, F. 1975: L'agriculture et le feu, rôle et place du feu dans les techniques de préparation du champ de l'ancienne agriculture européenne. EHESS, Mouton \& Co eds.

Stuiver, M. and Reimer, P.J. 1993: Extended 14C data base and revised calib 3.0 14C age calibration program. Radiocarbon 35, 215-30.

Talon, B. 1997: Evolution des zones supra-forestières des Alpes sud-occidentales françaises au cours de l'Holocène. Analyse pédoanthracologique. Thèse de $3^{\mathrm{e}}$ cycle. Université d'Aix-Marseille III.

Thinon, M. 1992: L'analyse pédoanthracologique, aspects méthodologiques et applications. Thèse ès sciences, Université d'Aix Marseille III.

Touflan, Talon, B., 2009. Spatial reliability of soil charcoal analysis: the case of subalpine forest soils. Ecoscience 16 (1), 23-27.

Trabaud L. 1989: Les feux de forêts, mécanismes, comportement et environnement. France-sélection eds, $278 \mathrm{p}$.

Trombold, C.D. and Israde-Alcantara, I. 2005: Paleoenvironment and plant cultivation on terraces at La Quemada, Zacatecas, Mexico: the pollen, phytolith and diatom evidence. Journal of Archaeological Science 32, 341-353.

Vannière B. 2001: Feu, agro-pastoralisme et dynamiques environnementales en France durant l'Holocène, analyse du signal incendie, approches sédimentologiques et études de cas en Berry, Pyrénées et Franche-Comté. Institut national agronomique Paris-Grignon, 327 p.

Vannière, B., Galop, D., Rendu, C. and Davasse, B. 2001: Feu et pratiques agro-pastorales dans les Pyrénées Orientales : le cas de la montagne d'Enveitg (Cerdagne, Pyrénées Orientales, France), SudOuest Européen, Environnement et anthropisation, 11, 29-42.

Walsh, K., Mocci, F., Court-Picon, M., Tzortzis, S., Palet-Martinez, J.M. 2005: Dynamique du peuplement et activités agro-pastorales durant l'âge du Bronze dans les massifs du Haut Champsaur et de l'Argentierois (Hautes-Alpes), Documents d'Archéologie méridionale 28 (2005), pp. 25-44.

Webb, E.A., Schwarcz, H.P. and Healy, P.F. 2004: Detection of ancient maize in lowland Maya coils using stable carbon isotopes: evidence from Caracol, Belize. Journal of Archaeological Science 31, 1039-1052. 
Bal, M.-C., Rendu C., Ruas M.-P., Campmajo P., 2010, Paleosol charcoal : Reconstructing vegetation history in relation to agro-pastoral activities since the Neolithic. A case study in the Eastern French Pyrenees. Journal of Archaeological Science, 37(2010) 1785-1797.

\section{Table 1}

Radiocarbon dated charcoals. Samples were extracted from soil and paleosol terraces. Calibrated dating was computed using the calibration program Calib5.

\begin{tabular}{|c|c|c|c|c|c|c|}
\hline Lab.-Nr & $\begin{array}{l}\text { Site- } \\
\text { terraces }\end{array}$ & Dated charcoal & Sample level and depth & Age ( ${ }^{14} \mathrm{C}$ yr BP) & $\begin{array}{l}\text { Calibrated years } \\
\text { BP }\end{array}$ & Cal. yr AD/BC $(2 \sigma)$ \\
\hline Poz-17564 & Cerd13 & $\begin{array}{l}\text { Pinus } \\
\text { sylvestris/uncinata }\end{array}$ & Organo-horizon surface & $1265+/-30$ & $\begin{array}{l}1167-1283 \\
P=0,91\end{array}$ & 667 (734) $783 \mathrm{cal}$ AD \\
\hline Poz-17560 & Cerd3bis & $\begin{array}{l}\text { Pinus } \\
\text { sylvestris/uncinata }\end{array}$ & $\begin{array}{l}\text { Organo-mineral surface, } \\
\text { Ah1 horizon; } 25 \mathrm{~cm}\end{array}$ & $2005+/-30$ & $\begin{array}{l}1881-2005 \\
P=0,97\end{array}$ & $56(61) 69 \mathrm{cal} \mathrm{AD}$ \\
\hline Vera-2951 & Cerd3bis & $\begin{array}{l}\text { Pinus } \\
\text { sylvestris/uncinata }\end{array}$ & $\begin{array}{l}\text { Organo-mineral horizon } \\
\text { of paleosol } 2 \mathrm{bAh} \text {, base of a } \\
\text { stone; } 60 \mathrm{~cm}\end{array}$ & $2745+/-30$ & $2768-2889 P=0.95$ & $940(881) 819 \mathrm{cal} \mathrm{BC}$ \\
\hline Poz-17561 & Cerd3bis & $\begin{array}{l}\text { Pinus } \\
\text { sylvestris/uncinata }\end{array}$ & $\begin{array}{l}\text { Organo-mineral horizon } \\
\text { Ah2; } 30 \mathrm{~cm}\end{array}$ & $3070+/-30$ & $\begin{array}{l}3215-3362 \\
P=1\end{array}$ & $\begin{array}{l}1413(1346) 1266 \mathrm{cal} \\
\mathrm{BC}\end{array}$ \\
\hline Poz-9153 & Cerd5bis & Abies alba & $\begin{array}{l}\text { Organo-mineral horizon } \\
\text { of paleosol } 2 \mathrm{bAh} ; 55 \mathrm{~cm}\end{array}$ & $3575+/-35$ & $3823-3977 P=0.91$ & $\begin{array}{l}2028(1927) 1874 \mathrm{cal} \\
\mathrm{BC}\end{array}$ \\
\hline Poz-17562 & Cerd6 & Abies alba & Horizon S, $65 \mathrm{~cm}$ & $3585+/-30$ & $\begin{array}{l}3829-3978 \\
P=0,99\end{array}$ & $\begin{array}{l}2029(1938) 1880 \mathrm{cal} \\
\mathrm{BC}\end{array}$ \\
\hline Vera-2949 & Cerd6 & Abies alba & $\begin{array}{l}\text { Lens on top of the organo- } \\
\text { mineral horizon of } \\
\text { paleosol; } 85 \mathrm{~cm}\end{array}$ & $3590+/-25$ & $3836-3933 P=0.84$ & $\begin{array}{l}1984(1943) 1887 \mathrm{cal} \\
\mathrm{BC}\end{array}$ \\
\hline Vera-2948 & Cerd3bis & Abies alba & $\begin{array}{l}\text { Organo-mineral horizon } \\
\text { of paleosol } 2 \mathrm{bAh} ; 58 \mathrm{~cm}\end{array}$ & $3730+/-20$ & $4067-4149 P=0.58$ & $2200(2133) 2118 \mathrm{cal} \mathrm{BC}$ \\
\hline Vera-3256 & Cerd13 & $\begin{array}{l}\text { Pinus } \\
\text { sylvestris/uncinata }\end{array}$ & $\begin{array}{l}\text { Before ancient wall of } \\
\text { terrace; } 95 \mathrm{~cm} \text {; level IV }\end{array}$ & $4090+/-40$ & $4512-4711 P=0.71$ & $\begin{array}{l}2762(2654) 2563 \mathrm{cal} \\
\mathrm{BC}\end{array}$ \\
\hline Vera-2694 & Cerd5 & Abies alba & $\begin{array}{l}\text { Lens on top of stone and } \\
\text { on base of organo-mineral } \\
\text { horizon of paleosol; } 70 \mathrm{~cm}\end{array}$ & $4120+/-30$ & $4528-4713 P=0.72$ & $\begin{array}{l}2764(2701) 2579 \mathrm{cal} \\
\mathrm{BC}\end{array}$ \\
\hline Vera-2950 & Cerd3bis & Abies alba & $\begin{array}{l}\text { Organo-mineral horizon } \\
\text { Ah2; } 30 \mathrm{~cm}\end{array}$ & $4135+/-25$ & $4569-4743 P=0.70$ & $\begin{array}{l}2794(2729) 2620 \mathrm{cal} \\
\mathrm{BC}\end{array}$ \\
\hline Vera-3255 & Cerd13 & Abies alba & $\begin{array}{l}\text { Inside wall of the ancient } \\
\text { terrace }\end{array}$ & $4185+/-35$ & $4612-4767 P=0.74$ & $\begin{array}{l}2818(2774) 2663 \mathrm{cal} \\
\mathrm{BC}\end{array}$ \\
\hline
\end{tabular}


Bal, M.-C., Rendu C., Ruas M.-P., Campmajo P., 2010, Paleosol charcoal : Reconstructing vegetation history in relation to agro-pastoral activities since the Neolithic. A case study in the Eastern French Pyrenees. Journal of Archaeological Science, 37(2010) 1785-1797.

Table 2

Field description of the Cerd6 terrace profile.

\begin{tabular}{lll}
\hline Depth/cm & Horizon & Macro morphology \\
\hline $\mathbf{0 - 1 5}$ & Ah1 & $\begin{array}{l}\text { Very dark greyish brown (10YR 3/2); sandy loam; few very } \\
\text { small stones; moderate fine granular; abundant roots; clear } \\
\text { boundary to }\end{array}$ \\
\hline $\mathbf{1 5 - 3 0}$ & Ah2 & $\begin{array}{l}\text { Greyish brown (10YR 5/2); sandy silt loam;few very small } \\
\text { stones; moderate fine granular; abundant roots and } \\
\text { earthworms tunnels; abrupt boundary to }\end{array}$ \\
\hline $\mathbf{3 0 - 6 0}$ & E & $\begin{array}{l}\text { Light greyish (10YR 5/4) horizon; sandy loam;clear boundary } \\
\text { to }\end{array}$ \\
\hline $\mathbf{6 0 - 8 0}$ & BP & $\begin{array}{l}\text { Red-brown (10YR 4/4) including aggregate; few very small } \\
\text { stones; abundant roots and earthworms tunnels; illuvial } \\
\text { horizon enriched in clay and ferric oxide; sharp boundary to }\end{array}$ \\
\hline $\mathbf{8 0 - 1 2 0}$ & 2bAh & $\begin{array}{l}\text { Very dark greyish brown (10YR 3/2); sandy silt loam; terrace } \\
\text { wall; strong fine granular; abundant micro-roots; Abies alba } \\
\text { charcoal lens on top; sharp boundary to }\end{array}$ \\
\hline $\mathbf{1 5 0 - 2 0 0}$ & C & $\begin{array}{l}\text { Yellowish ochre (10YR 5/8); sandy silt; crumbly structure; } \\
\text { medium stones; clear boundary to }\end{array}$ \\
\hline $\mathbf{2 0 0 - b a s e}$ & R & $\begin{array}{l}\text { Yellow (10YR 7/8); sandy loam; medium and large stones; } \\
\text { clear boundary to }\end{array}$ \\
\hline
\end{tabular}

Table 3

Field description of the Cerd5 and Cerd5bis terrace profile.

\begin{tabular}{|c|c|c|}
\hline Depth/cm & Horizon & Macromorphology \\
\hline $0-7$ & Ah1 & $\begin{array}{l}\text { Very dark greyish brown (10YR } 3 / 2) \text {; sandy loam; few very } \\
\text { small stones; moderate fine granular; abundant roots; clear } \\
\text { boundary to }\end{array}$ \\
\hline $7-20$ & Ah2 & $\begin{array}{l}\text { Greyish brown (10YR 5/2); sandy silt loam; few very small } \\
\text { stones; moderate fine granular; abundant roots and } \\
\text { earthworms tunnels; abrupt boundary to }\end{array}$ \\
\hline $20-40$ & $\mathrm{BP}$ & $\begin{array}{l}\text { Pale brown (10YR 6/3); sandy silt loam; few very small } \\
\text { stones; medium subangular blocky; few roots; abrupt } \\
\text { boundary to }\end{array}$ \\
\hline $40-60$ & $2 \mathrm{bAh}$ & $\begin{array}{l}\text { Very dark greyish brown (10YR } 3 / 2) \text {; sandy silt loam; } \\
\text { terrace wall; strong fine granular; abundant micro-roots; } \\
\text { charcoals; sharp boundary to } 60-80\end{array}$ \\
\hline 80-100 & $\mathrm{C}$ & $\begin{array}{l}\text { Yellow (10YR } 7 / 8) \text {; sandy loam; medium and large stones; } \\
\text { clear boundary to }\end{array}$ \\
\hline 100-base & $\mathrm{R}$ & Granit substrate \\
\hline
\end{tabular}


Bal, M.-C., Rendu C., Ruas M.-P., Campmajo P., 2010, Paleosol charcoal : Reconstructing vegetation history in relation to agro-pastoral activities since the Neolithic. A case study in the Eastern French Pyrenees. Journal of Archaeological Science, 37(2010) 1785-1797.

\section{Table 4}

Field description of the Cerd13 terrace profile.

\begin{tabular}{|c|c|c|}
\hline Depth/cm & Horizon & Macromorphology \\
\hline 0-10 & Ah1 & $\begin{array}{l}\text { Very dark greyish brown (10YR } 3 / 2) \text {; sandy } \\
\text { loam; few very small stones; moderate fine } \\
\text { granular; abundant roots; clear boundary to }\end{array}$ \\
\hline $10-40$ & Ah2 & $\begin{array}{l}\text { Greyish brown (10YR 5/2); sandy silt loam; } \\
\text { few very small stones; moderate fine granular; } \\
\text { abundant roots and earthworms tunnels; } \\
\text { abrupt boundary to }\end{array}$ \\
\hline $40-70$ & $\mathrm{E}$ & $\begin{array}{l}\text { Very pale brown (10YR } 7 / 3) \text {; sandy silt loam; } \\
\text { few very small stones; fine subangular blocky; } \\
\text { many roots; clear boundary to }\end{array}$ \\
\hline 70-90 & BP & $\begin{array}{l}\text { Brown (10YR 5/3); sandy loam; few very } \\
\text { small stones; medium subangular blocky; few } \\
\text { roots; abrupt boundary to }\end{array}$ \\
\hline $90-140$ & $2 \mathrm{bAh}$ & $\begin{array}{l}\text { Very dark greyish brown (10YR } 3 / 2) \text {; sandy } \\
\text { silt loam; terrace wall; strong fine granular; } \\
\text { abundant micro-roots; charcoals; sharp } \\
\text { boundary to }\end{array}$ \\
\hline 140-150 & Sal & $\begin{array}{l}\text { Yellowish ochre horizon (10YR 5/8); sandy } \\
\text { silt loam; crumbly structure; medium and } \\
\text { large stones; clear boundary to }\end{array}$ \\
\hline $150-160$ & $\mathrm{C}$ & $\begin{array}{l}\text { Yellowish (10YR 7/8); sandy loam; medium } \\
\text { and large stones; clear boundary to }\end{array}$ \\
\hline 160-base & $\mathrm{R}$ & Granit substrate \\
\hline
\end{tabular}

Table 5

Field description of the Cerd3bis terrace profile.

\begin{tabular}{|c|c|c|}
\hline Depth/cm & Horizon & Macromorphology \\
\hline $0-3$ & $\mathrm{~A} 0 \mathrm{~A} 1$ & $\begin{array}{l}\text { Very dark greyish brown (10YR } 3 / 2) \text {; sandy loam; } \\
\text { few very small stones; moderate fine granular; } \\
\text { abundant roots and micro-roots; abrupt boundary } \\
\text { to }\end{array}$ \\
\hline $3-25$ & Ah1 & $\begin{array}{l}\text { Brown (10YR 5/3); loamy sand; few very small } \\
\text { stones; moderate fine granular; abundant roots; } \\
\text { clear boundary to }\end{array}$ \\
\hline $25-45$ & Ah2 & $\begin{array}{l}\text { Brown (10YR 4/3); loamy sand; few very small } \\
\text { stones; moderate fine granular; abundant roots; } \\
\text { sharp boundary to }\end{array}$ \\
\hline $45-65$ & $2 \mathrm{bAh}$ & $\begin{array}{l}\text { Dark yellowish brown (10YR 3/4); sandy silt } \\
\text { loam; terrace wall; strong fine granular; abundant } \\
\text { micro-roots; charcoals; sharp boundary to }\end{array}$ \\
\hline $65-75$ & Sal & $\begin{array}{l}\text { Yellowish brown (10YR 5/8); sandy silt loam; } \\
\text { crumbly structure; medium and large stones; clear } \\
\text { boundary to }\end{array}$ \\
\hline $75-80$ & $\mathrm{C}$ & $\begin{array}{l}\text { Yellowish (10YR 7/8) horizon; sandy loam; } \\
\text { medium and large stones; clear boundary to }\end{array}$ \\
\hline $80-90$ & M & Yellowish brown (10Y/R 5/6) layer; \\
\hline 90-base & $\mathrm{R}$ & Granite substrate \\
\hline
\end{tabular}


Bal, M.-C., Rendu C., Ruas M.-P., Campmajo P., 2010, Paleosol charcoal : Reconstructing vegetation history in relation to agro-pastoral activities since the Neolithic. A case study in the Eastern French Pyrenees. Journal of Archaeological Science, 37(2010) $1785-1797$.

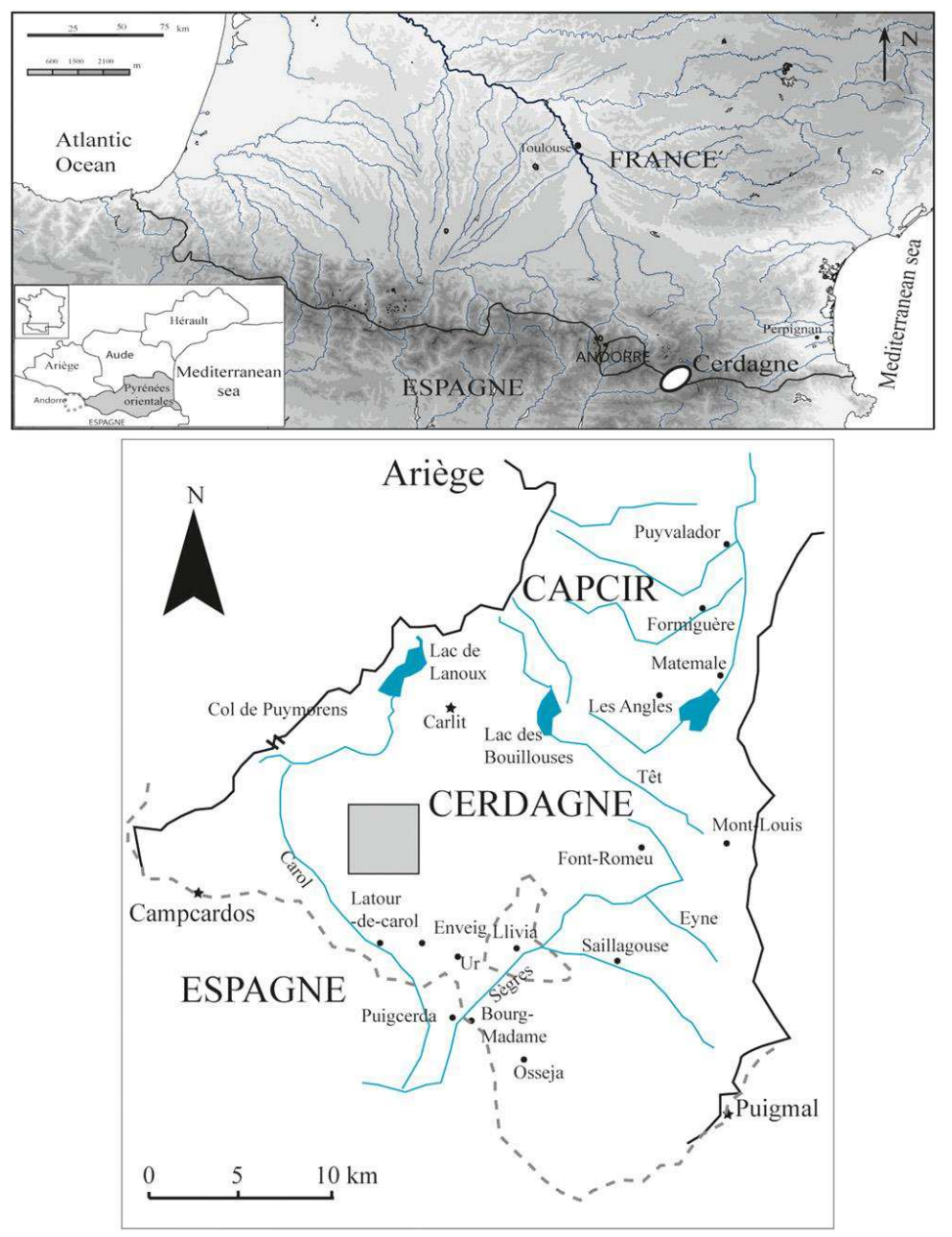

Fig. 1. Location of Cerdagne and Enveig Mountain 
Bal, M.-C., Rendu C., Ruas M.-P., Campmajo P., 2010, Paleosol charcoal : Reconstructing vegetation history in relation to agro-pastoral activities since the Neolithic. A case study in the Eastern French Pyrenees. Journal of Archaeological Science, 37(2010) 1785-1797.

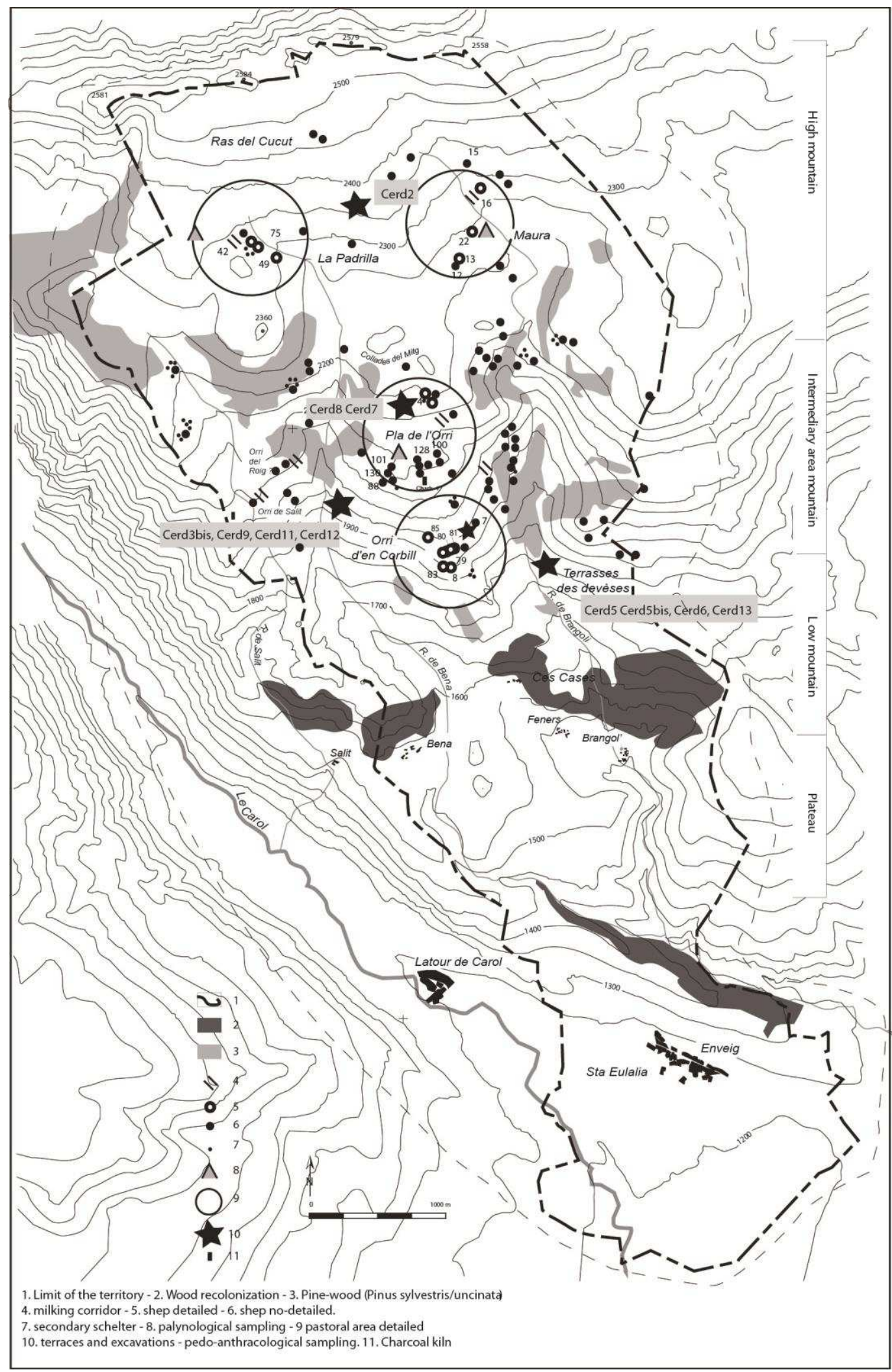

Fig. 2. Locations of soil charcoal sampling, peat bog, archaeological sites in the Enveig slope. 
Bal, M.-C., Rendu C., Ruas M.-P., Campmajo P., 2010, Paleosol charcoal : Reconstructing vegetation history in relation to agro-pastoral activities since the Neolithic. A case study in the Eastern French Pyrenees. Journal of Archaeological Science, 37(2010) 1785-1797.

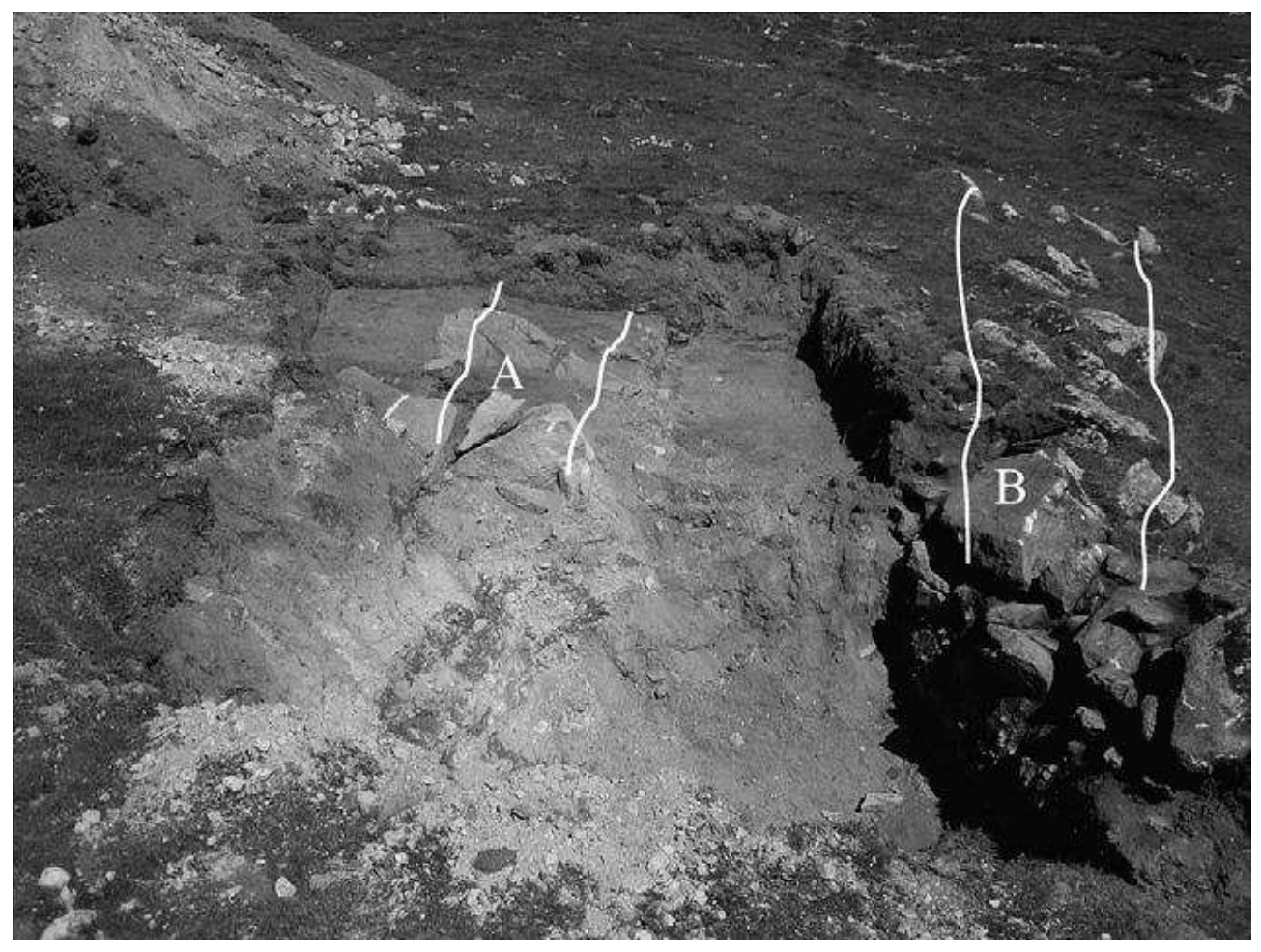

Fig. 3. An example of terrace excavation at $1900 \mathrm{~m}$ altitude. (A): Alignments of stones of buried terrace; (B): wall of the second stage of terraces. 
Bal, M.-C., Rendu C., Ruas M.-P., Campmajo P., 2010, Paleosol charcoal : Reconstructing vegetation history in relation to agro-pastoral activities since the Neolithic. A case study in the Eastern French Pyrenees. Journal of Archaeological Science, 37(2010) 1785-1797.

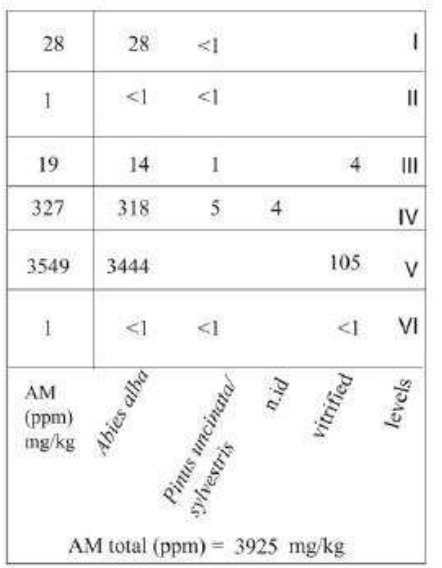

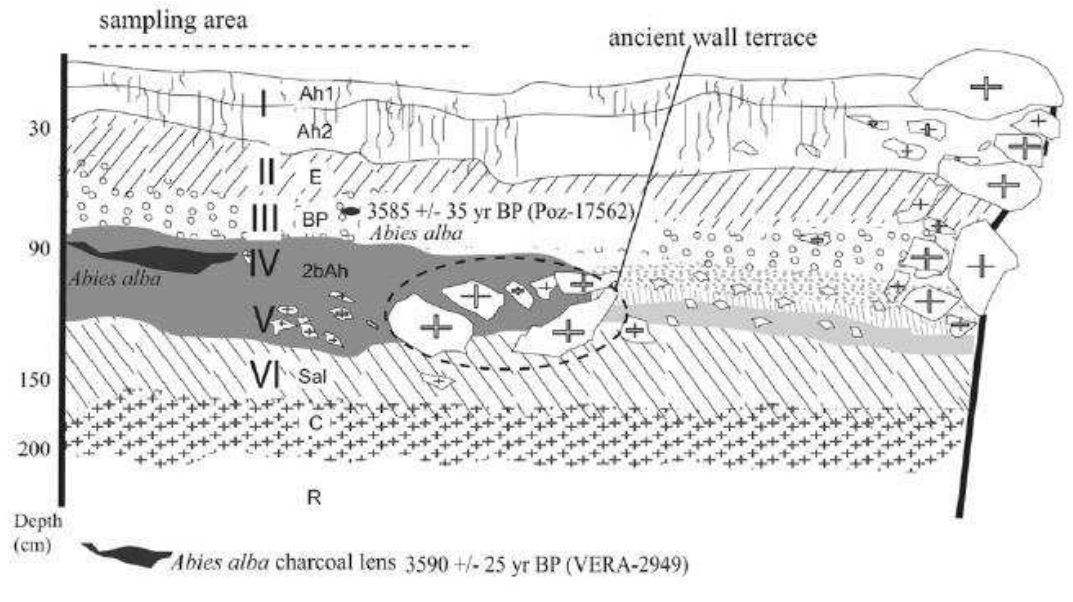

\footnotetext{
$\square$ Very dark greyish brown surface organo-mineral horizon (Ah1). And a greyish brown organo-mineral horizon (Ah2). Numerous micro-roots.

Q. Light greyish horizon (E).

8:: Red-brown horizon (BP), very dense micro-roots/ numerous earthworm tunnels.

MIV Yellowish ochre horizon (Sal).

Paleosol organo-mineral horizon (2bAh).
}

\author{
B.i.i. Brown-dark horizon. \\ Horizon ochre \\ Grey horizon. \\ $+_{+}^{+}++^{+}$Granite substrate deterioration (C).
}

Fig. 4. Cerd6 excavation, anthracomass and identification of charcoal (Baise et al., 1995; Munsell, 1994). 
Bal, M.-C., Rendu C., Ruas M.-P., Campmajo P., 2010, Paleosol charcoal : Reconstructing vegetation history in relation to agro-pastoral activities since the Neolithic. A case study in the Eastern French Pyrenees. Journal of Archaeological Science, 37(2010) $1785-1797$.

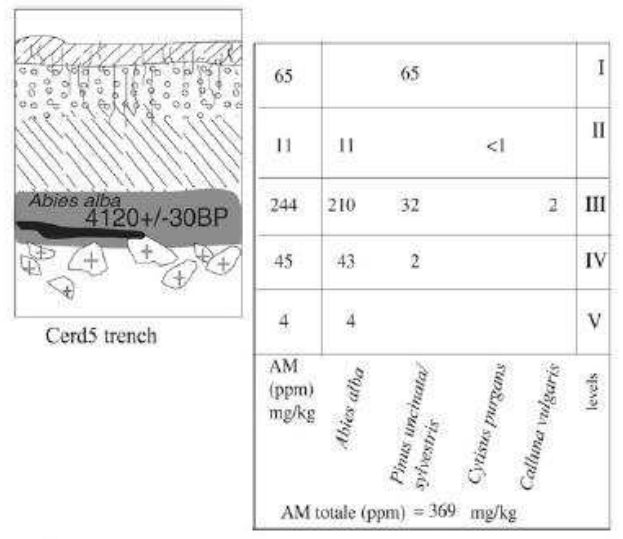

Q7. Surface organo-mineral horizon (Ahl). Numerous micro-roots.

S: Organo-mineral horizon (Ah2), very dense micro-roots/ numerous earthworm tunnels.

Aiv Sandy horizon (BP).

Paleosol organo-mineral horizon (2bAh).

Paleosol horizon (Sal).

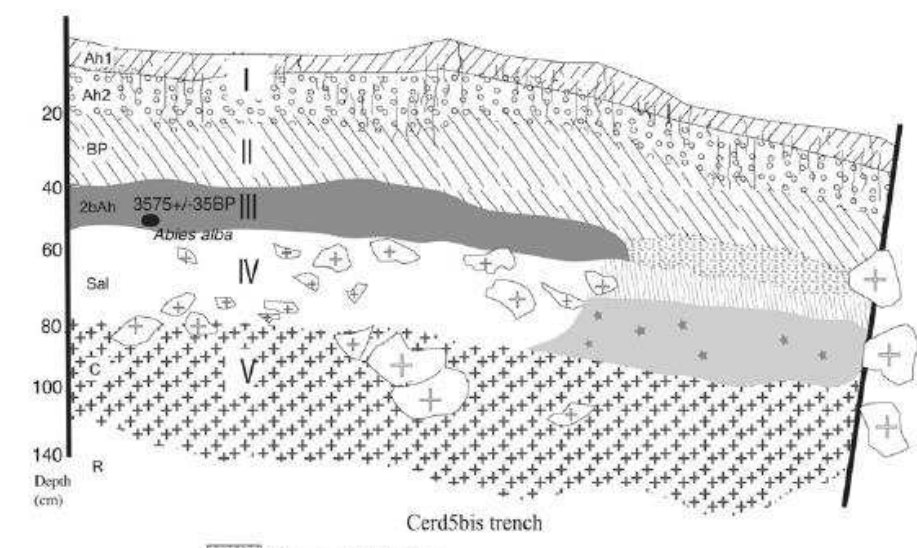

Arown-dark horizon.

Whiching ochre

$x *$ Grey horizon.

${ }_{+}^{+{ }^{+}+}+$Granite substrate deterioration (C).

Fig. 5. Cerd5 and Cerd5bis excavations, anthracomass and identification of charcoal. 
Bal, M.-C., Rendu C., Ruas M.-P., Campmajo P., 2010, Paleosol charcoal : Reconstructing vegetation history in relation to agro-pastoral activities since the Neolithic. A case study in the Eastern French Pyrenees. Journal of Archaeological Science, 37(2010) 1785-1797.

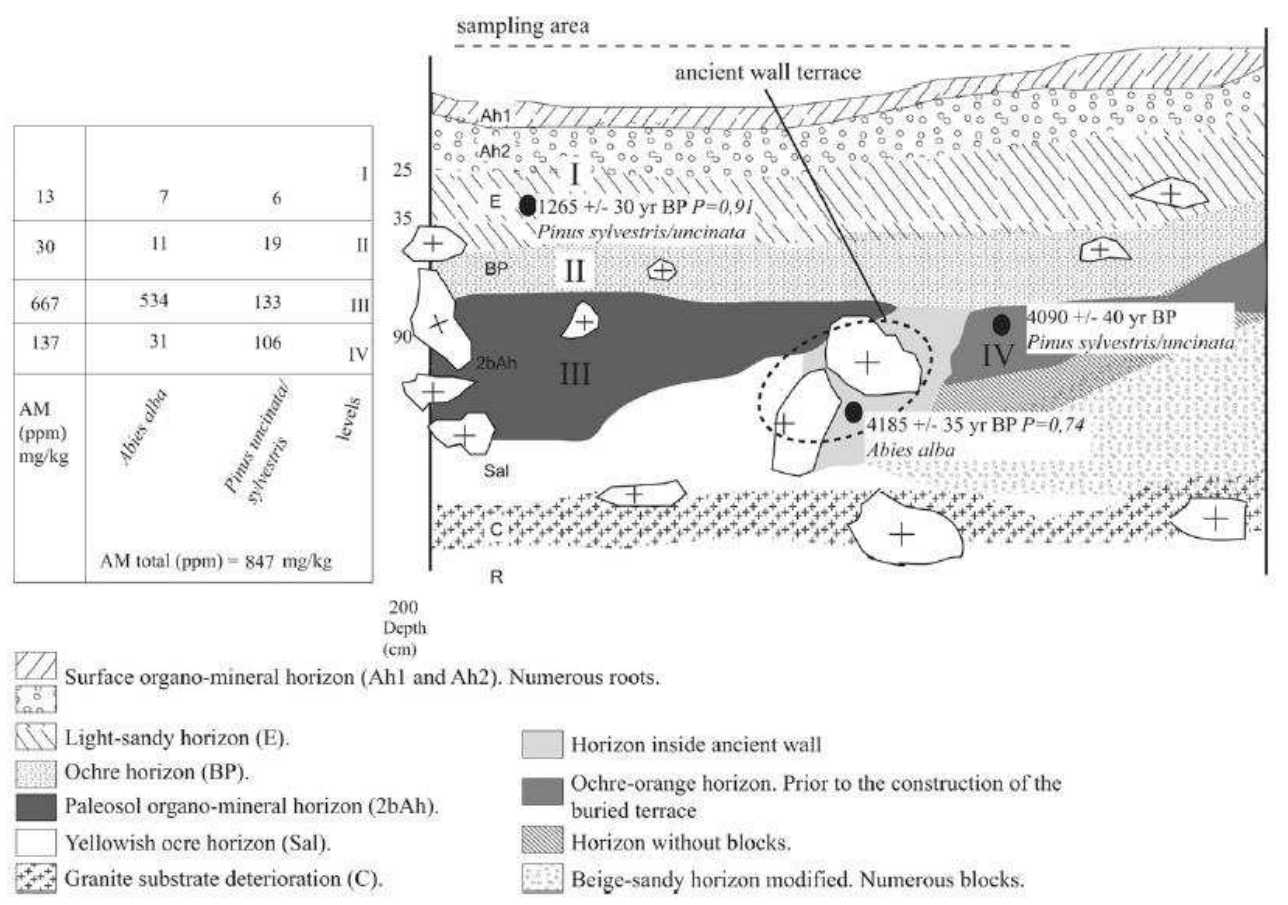

Fig. 6. Cerd13 excavation, anthracomass and identification of charcoal. 
Bal, M.-C., Rendu C., Ruas M.-P., Campmajo P., 2010, Paleosol charcoal : Reconstructing vegetation history in relation to agro-pastoral activities since the Neolithic. A case study in the Eastern French Pyrenees. Journal of Archaeological Science, 37(2010) 1785-1797.

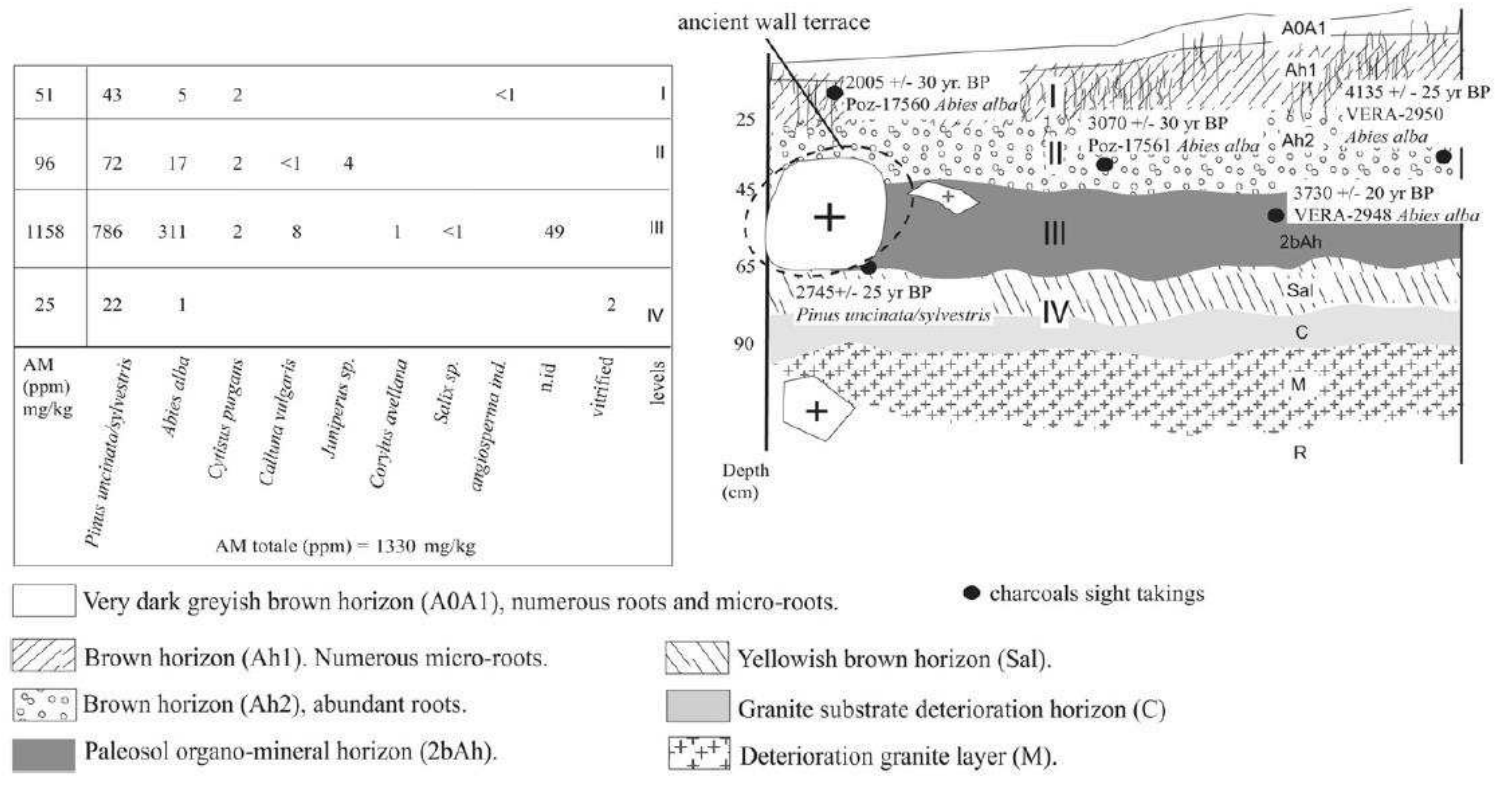

Fig. 7. Cerd3bis excavation, anthracomass and identification of charcoal. 